2002 December 31

Cooperative Agreement

No. DE-FC07-97ID13567

\title{
Wettable Ceramic-Based Drained Cathode Technology for Aluminum Electrolysis Cell
}

Final Technical Progress Report for the Period 1997 October through 2002 December

Submitted to:

U. S. Department of Energy

Idaho Operations Office

850 Energy Drive

Idaho Falls, Idaho 83401-1563 
DOE/ID/13567

\title{
Wettable Ceramic-Based Drained Cathode Technology for Aluminum Electrolysis Cell
}

\author{
Submitted to: \\ U. S. Department of Energy \\ Cooperative Agreement Number DE-FC07-97ID13567 \\ Submitted by: \\ J. N. Bruggeman \\ T. R. Alcorn \\ R. Jeltsch \\ T. Mroz \\ Alcoa Inc. \\ 100 Technical Drive \\ Alcoa Center, PA 15069-0001
}

2002 December 31

This material is based upon work supported by the U.S. Department of Energy under Award No. DE-FC07-97ID13567. Any opinions, findings, and conclusions or recommendations expressed in this material are those of the authors and do not necessarily reflect the views of the Department of Energy. 
TABLE OF CONTENTS

Page No.

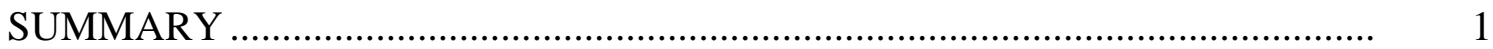

INTRODUCTION

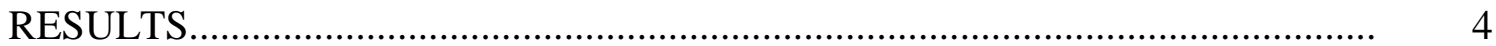

Program Time Line .............................................................................

Laboratory Scale Testing/Evaluation ............................................................... 4

Pilot Cell Testing.......................................................................................

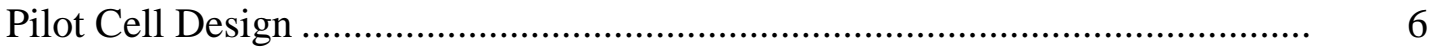

Tile Design and Attachment........................................................................... 8

Tile Preparation and Installation for the First Pilot Cell ..................................... 9

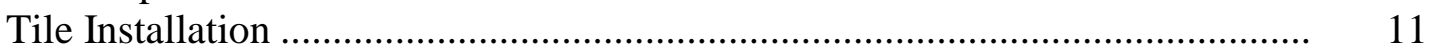

Pilot Cell 1 Operation................................................................................ 15

Pilot Cell 2 Operation................................................................................. 20

Tile Material Composition and Configuration ............................................. 21

Operational Performance............................................................................. 22

Viability of End Sump Design .................................................................. 23

Thermal Design ....................................................................................... 24

Operational Procedures .......................................................................... 25

Industrial Cell Design................................................................................. 26

Basic Design Philosophy ........................................................................ 26

Design Process Description........................................................................... 27

Industrial Cell Design............................................................................ 27

"Scaledown" of Industrial Cell to Pilot Cell ..................................................... 31

Results of Operation of Pilot Cell 1 as Applied to Lining Design...................... 31

Design of Pilot Cell 2 .................................................................................. 31

Results of Operation of Pilot Cell 2 as Applied to Lining Design..................... $\quad 31$

Redesign of Industrial Cell........................................................................... 32

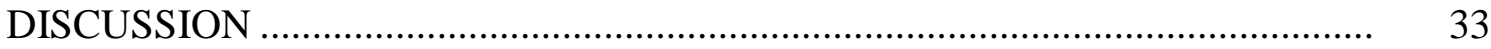

Appendix A: Project Scope Description ……………………………………..... 35

Statement of Objectives ............................................................................... 36

Introduction ..................................................................................... 36

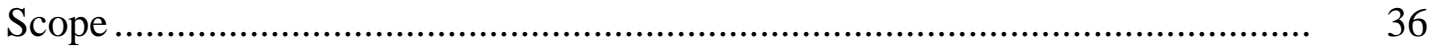

Task 1: Material Development.......................................................................... 37

Subtask 1.1: Develop Sample Materials for the Laboratory Tests ....... $\quad 37$

Subtask 1.2: Develop Quality Control Program ................................... 37

Subtask 1.3: Laboratory Scale Tests of the Sample TiB2 and "312"

Based Materials

Task 2: Evaluation of "312" and TiB2 Materials in 23 kA Drained

Pilot Reduction Cell ........................................................................ 38

Task 3: Development of Engineering Packages and Confirmation of the Economics for Industrial Cells Operating with TiB2-DrainedCathodes 39

Task 4: Project Management and Reporting ....................................................... 39 
Appendix B: List of Publications .................................................................. 41

Appendix C: Patent Application(s) Generated Under Contract .............................. 42 


\section{SUMMARY}

Alcoa (formerly Reynolds Metal Company), Kaiser Aluminum, and M/A Com (formerly Advanced Refractory Technologies, Inc.) jointly developed the necessary ceramic based materials, technology, and engineering packages to retrofit existing aluminum reduction cells in a drained cathode configuration as part of a joint cost-shared research program with the U.S. Department of Energy (DOE). During this program materials were initially screened in laboratory evaluations and eventually tested in a $23 \mathrm{kA}$ pilot reduction cell.

Laboratory scale testing evaluating $\mathrm{TiB}_{2}$ and $\mathrm{Ti}_{3} \mathrm{SiC}_{2}(312)$ based materials in a cryolitic environment were conducted, with primary emphasis on wetability of the materials by aluminum and ability to withstand the corrosive environment of the cryolitic melt. Primary results from this phase of the program are:

- Tile materials need not be dense to provide sufficient mechanical, electrical and corrosion performance for the smelting cathode application.

- $\mathrm{TiB}_{2}$ can be combined with chopped carbon fibers to create composite components with reasonable physical and electrical characteristics. Composites with carbon fiber contents from $0-40 \%$ were created. Physical properties begin to degrade at fiber contents over $20 \%$.

- $\mathrm{Ti}_{3} \mathrm{SiC}_{2}$ (312) was successfully prepared using several synthesis methods. Obtaining pure $\mathrm{Ti}_{3} \mathrm{SiC}_{2}$ without $\mathrm{TiC}$ contamination was exceedingly difficult. However, TiC was not found to degrade the performance of 312 in benchtop corrosion testing.

Based on these initial material evaluations, eight different materials were selected for testing in a $23 \mathrm{kA}$ pilot cell. The pilot cell was designed to mimic the full sized industrial cell at Kaiser's Mead facility as much as possible. To do this the concept of the industrial cell was developed and modeled, then the pilot cell design developed. Key aspects of the industrial cell design and pilot cell are as follows:

- An end sump at the tap end of the cell provided metal collection from the cell

- Anodes carrying reduced current located partially over the sump provided sufficient thermal cover for the sump

- Hexagonal shaped ceramic based materials with interlocking tabs laid on top of the carbon blocks provided the wettable based cathode surface

The first pilot cell performance clearly showed that the ceramic cathode surface allowed for aluminum wetting as designed, and cell operations generally went smoothly. During operations, high Ti levels were observed in the recovered aluminum. This suggested that tile degradation was occurring in at least a portion of the tile array. Physical evaluation of the tile surface provided evidence that the tile surface was physically disrupted in some areas. Despite these observations, the cell operated well in both drained and metal pad modes. 
Evaluation of the tiles used in the first pilot cell operation showed that:

- 312 materials exhibited exceedingly poor performance in pilot cell tests, despite excellent results in benchtop tests. Thus, the value and validity of the benchtop screening test is suspect.

- $\mathrm{TiB}_{2}-\mathrm{C}$ tiles fared better, with low carbon samples exhibiting the best performance.

- The hexagonal shaped interlocking tiles provided a sufficient restraint mechanism for the tiles to remain in place, despite significant deterioration in a large number of tiles.

The second pilot cell was operated for 60 days using the best performing tiles from the first operation. Results from this operation showed the following.

- Confirmed best material composition as those with low carbon content was capable of surviving long term in molten aluminum/bath environment

- Confirmed a suitable method for installation of tiles using the interlocking hexagonal design

- Confirmed operation at 1" anode-tile distance

- Confirmed concept and viability of drained end-sump operation

- Demonstrated operation with enhanced cathode package

- Develop operational procedures for industrial cell

- Demonstrated the need to protect the sump from erosion/dissolution during operation

- Demonstrated the need to develop suitable industrial cell procedure for extinguishing anode effects

- Demonstrated the need to assure a proper thermal balance is maintained in the cell operation

Industrial cell testing was the next planned step in this program, but due to the power situation in the Northwest and Kaiser Mead's plant shutdown, this phase of the program is not scheduled at this time. The results of the testing to date do indicate that a suitable wettable cathode material and design has been identified. Industrial cell testing is required to fully evaluate this design, with particular attention being given to the thermal design, sump protection, and anode effect extinguishing procedures. 


\section{INTRODUCTION}

Alcoa (formerly Reynolds Metals Company) participated in a U.S. Department of Energy (DOE) sponsored and cost-shared project entitled "Wettable Ceramic-Based Drained Cathode Technology for Aluminum Electrolysis Cells" as cooperative agreement DEFC07-47ID13567. Kaiser Aluminum and Chemical Company and M/A-COM (formerly Advanced Refractory Technologies, Inc.) were subcontracted as cost shared partners. The goal of the project was to develop the ceramic based materials, technology, and necessary engineering packages to retrofit existing aluminum reduction cells in order to reduce energy consumption required for making primary aluminum. The ceramic materials would be used in a drained cathode configuration which would provide a stable, molten aluminum wetted cathode surface, allowing the reduction of the anode-cathode distance, thereby reducing the energy consumption.

This multi-tasked project was divided into three major tasks: 1) Manufacturing and laboratory scale testing/evaluation of the ceramic materials, 2) Pilot scale testing of qualified compositions from the first task, and 3) Designing, retrofitting, and testing the ceramic materials in industrial cells at Kaiser Mead plant in Spokane, Washington. Specific description of these major tasks can be found in Appendix A - Project Scope. Due to the power situation in the northwest, the Mead facility was closed, thus preventing the industrial cell testing.

This report will serve as documentation of the results of this test program. 


\section{RESULTS}

\section{Program Time Line}

This program was initiated in October of 1997 and continued through completion of the pilot cell operation in October of 2000. The project remained opened until 2002 due to the uncertainness associated with the Kaiser Mead closure. The key events during this program are summarized below.

- Contract initiated

- Kaiser Mead Facility Union begins Strike

- Began installation of larger rectifiers at STLab

- Began first pilot cell operation

- Reynolds Metals Company acquired by Alcoa

- Began second pilot cell operation

- Kaiser Mead Facility announced temporary closure

- ART acquired by M/A-COM
October, 1997

October, 1998

April, 1999

October, 1999

May, 2000

August, 2000

December, 2000

June, 2001

\section{Laboratory Scale Testing/Evaluation}

During the first two years of the project, work was directed toward evaluating numerous material compositions and fabrication methods in quick laboratory evaluations. The overall goal was to screen numerous materials for selection of the best candidates in pilot scale testing. ART had primary responsibility for this part of the project, with Reynolds Metals providing the necessary laboratory testing of the elements.

This part of the materials development program had several significant goals:

- Synthesize sufficient amounts of a new compound, $\mathrm{Ti}_{3} \mathrm{SiC}_{2}$ (312) to test for cathode applications.

- Develop scaleable and industrially sound processing methods for forming large tile shapes from 312 and $\mathrm{TiB}_{2}$ materials.

- Investigate potential means of applying suitable ceramic materials directly to graphite as a coating.

- Obtain basic materials properties on candidate materials.

Initial efforts focused on a variety of preparatory activities including:

- Materials synthesis

- Processing development

- Materials testing

- Design for benchtop testing

- Early tile shape and attachment design activities 
During this period, significant progress was made in identifying and testing a wide variety of materials applicants in preliminary benchtop corrosion conditions. Unfortunately, the corrosion testing was not sufficiently selective, and many candidate test materials appeared to display suitable performance characteristics. Thus, downselection of candidates to a reasonable number of compositions required further and more aggressive testing. Additionally, a means of ranking materials by anticipated cost was added to the selection criteria.

The more aggressive benchtop testing was pursued as a means of downselecting candidates for pilot cell tests. Samples in tile shape were tested in a bench scale simulation of a drained cell under electrolysis conditions. Unfortunately, due to limitations of the cell, test operations could only be performed for about 24 hours before the cell required disassembly. Many materials continued to appear to be reasonable candidates after this testing.

Much of the 312 material synthesis, cost reduction, evaluation and processing development was performed during this time, and is treated in this document. Scale improvements from 100 grams quantities to many $\mathrm{Kg}$ quantities were demonstrated, providing for sufficient material for component testing, as well as reducing estimated material costs.

Additional efforts were performed on coating development during this timeframe. While systems of preparing candidate materials in slurry and paste form were successfully developed, identifying suitable additives for low-temperature (i.e., $<1000^{\circ} \mathrm{C}$ ) hardening of the coating was less productive. Many candidate additives were deemed unlikely to survive cell conditions, particularly contact with molten bath. Ceramic bonding aids such as silica and aluminum oxide were in this group. Phenolic carbon glues were also considered, and samples were prepared that provided excellent coverage and rigid, bonded coatings upon firing. Unfortunately, benchtop testing showed that the carbon also was degraded by cell conditions. Thus, efforts in coating development were abandoned in favor of the tile approach.

Primary results from this phase of the program are:

- Tile materials need not be dense to provide sufficient mechanical, electrical and corrosion performance for the smelting cathode application.

- $\mathrm{TiB}_{2}$ can be combined with chopped carbon fibers to create composite components with reasonable physical and electrical characteristics. Composites with carbon fiber contents from $0-40 \%$ were created. Physical properties begin to degrade at fiber contents over about $20 \%$.

- $\mathrm{Ti}_{2} \mathrm{SiC}_{2}$ (312) was successfully prepared using several synthesis methods. Obtaining pure $\mathrm{Ti}_{3} \mathrm{SiC}_{2}$ without $\mathrm{TiC}$ contamination was exceedingly difficult. However, TiC was not found to degrade the performance of 312 in benchtop corrosion testing.

- Gel-based processing was successfully used to produce large, flat tile preforms using relatively low, uniaxial pressure, thereby minimizing equipment requirements and related costs. 


\section{Pilot Cell Testing}

In the original proposal for this project written in 1997, the anticipated operation of the pilot cell was to be $12 \mathrm{kA}$; however, additional rectifiers became available for use on this project, allowing operation up to $25 \mathrm{kA}$. This allowed designing a cell about $1 / 3$ the size of the intended industrial cell test. With the higher rectifier capacity, the pilot cell testing now provided a much more realistic evaluation of not only the ceramic tiles, but cell operation as well. With this in mind the pilot cell design was "backed" into, by first designing the basics of the industrial cell, and then implementing the necessary design changes for the pilot operation. Discussion of the industrial cell design can be found in "Industrial Cell Design Section." During the pilot scale testing, two runs of the pilot cell were completed. The first served primarily as a final screening of the best ceramic tile materials from the laboratory testing and initial evaluation of cell operation; while the second operation allowed more extended testing of the best material as well as longer term operational evaluation.

\section{Pilot Cell Design}

Key aspects of the pilot cell design were:

1. Basic design was settled as $1 / 3$ of a standard Mead cell (8 of 24 anodes). Full sized Mead anodes were to be used, and the cathode shell was to be the same width as a standard Mead cell.

2. An end sump was to be used.

3. Sump size and shape were to be as designed for the full sized cell.

4. The two end anodes (partially over the sump) would be connected to the permanent bridge, allowed to carry current but at reduced levels than standard anodes.

5. The cathode lining was scaled down to fit the length of the pilot cell shell. Insulation thicknesses were not changed. Cathode heat loss was calculated using Kaiser's thermal model.

6. Due to different surface to volume ratio of the pilot cell in reference to the industrial cell, the anode current density was adjusted upward by $19 \%$ to yield the proper thermal balance at the same target anode-cathode distance as the industrial cell. 
A schematic and picture of the pilot cell are shown below.

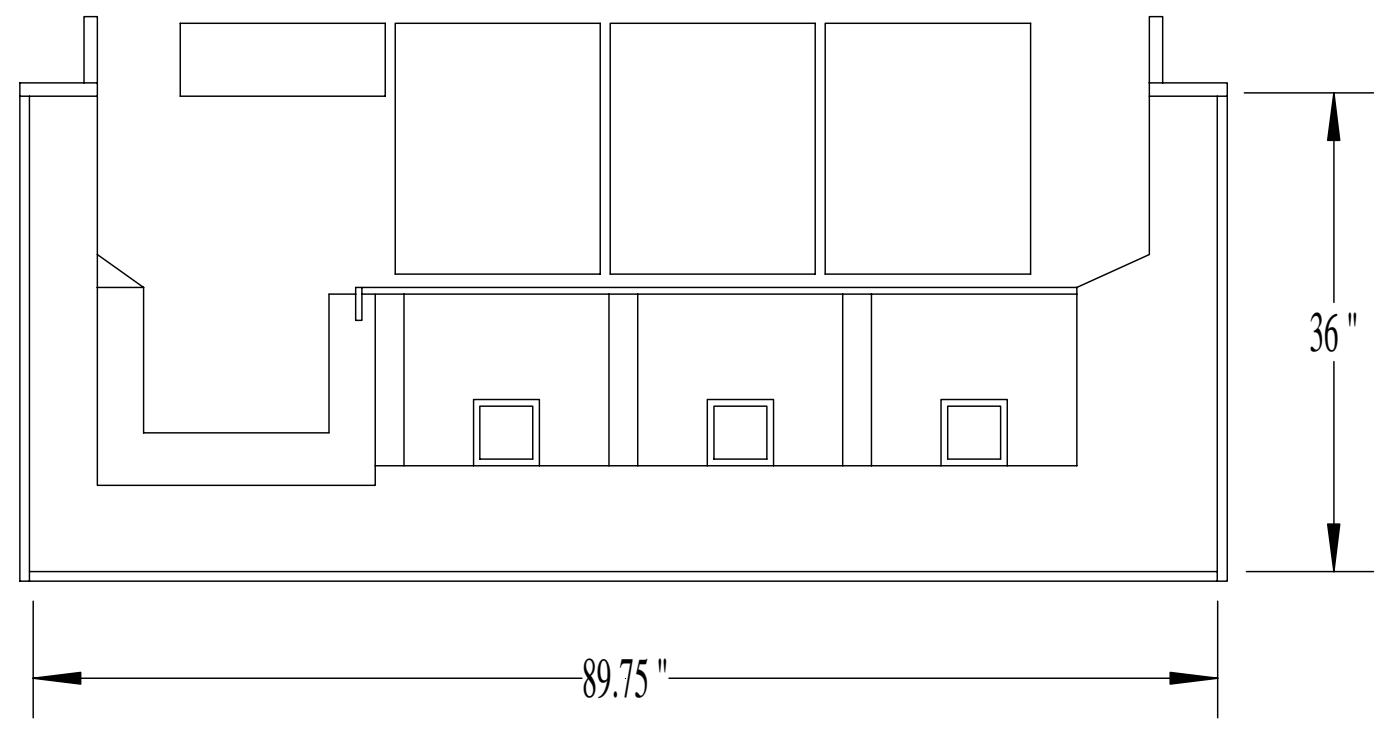

Figure 1 - Pilot Cell Schematic Showing End Sump Design

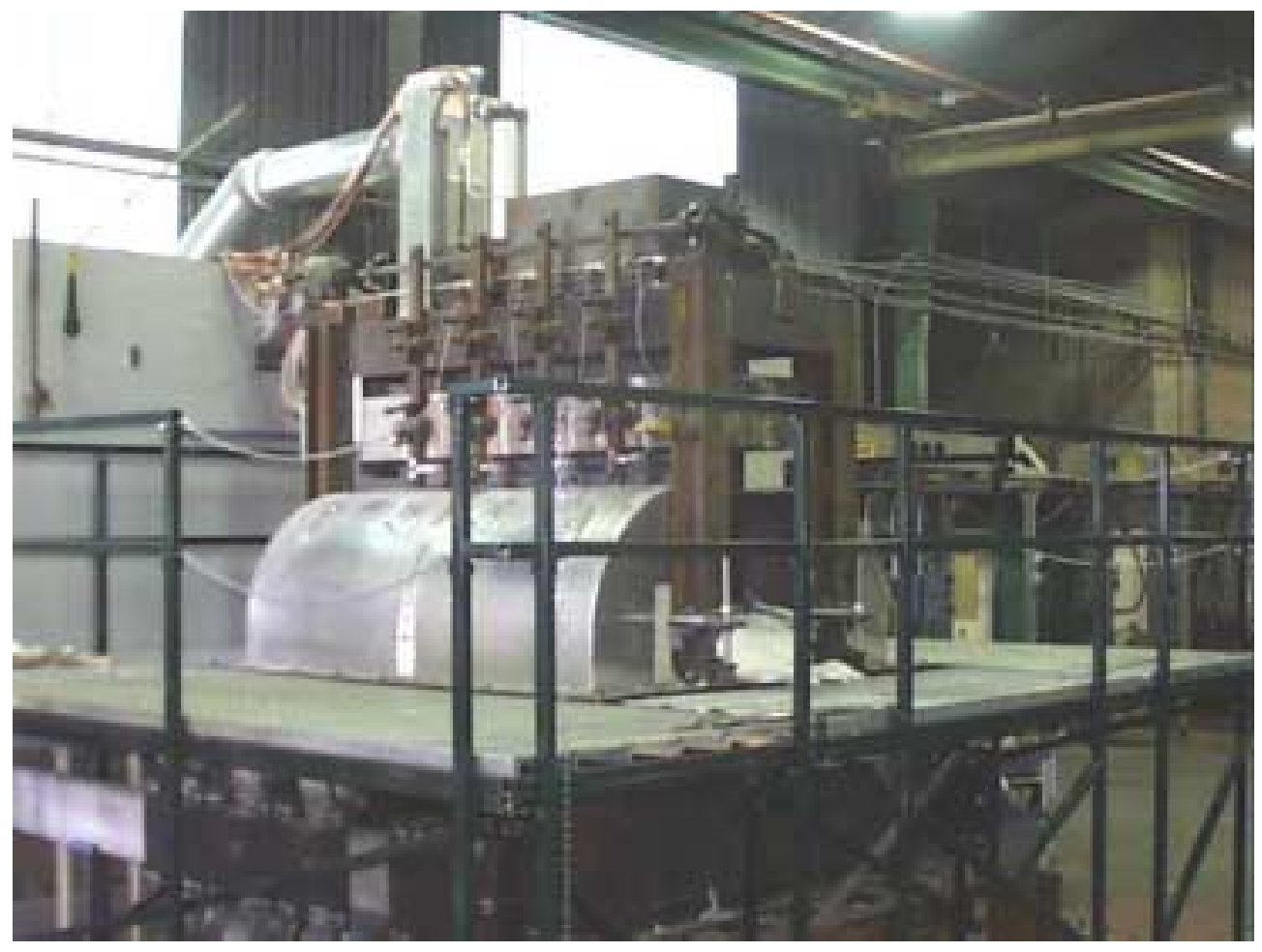

Figure 2 - Pilot Cell Facility 


\section{Tile Design and Attachment}

One of the most important issues in the project was the attachment of the materials to cathode blocks. Previous work concentrated on either rectangular tiles of various dimensions and thicknesses that were pinned to the cathode blocks or items that rose above the cathode block surface. These were attached to the cathode blocks either by setting directly into the cathode blocks or by the use of pins set into the blocks to act as holddowns. These methods were used in previous experiments, most notably the Reynolds and Great Lakes Carbon test, which evaluated a "mushroom" cathode design. Most of these projects however, were unsuccessful due to the failure of these attachment methods. Another method discussed was the use of cementitious glue to act as hold-downs. These were likely to be unsuccessful due to the creation of unstable aluminum carbide in the carbonaceous cement and the eventual removal of adhesion.

The method that appeared to be the most suitable uses interlocking tiles (Figure 3). Team members decided that this configuration would minimize planar movement due to the movement of the aluminum pad during operation. This configuration would use the neighboring tiles to supply a "hold-down" force to keep the tiles from becoming loose and moving about the cell. This design would eliminate the use of chemically unstable glues or mechanically weak pinning.

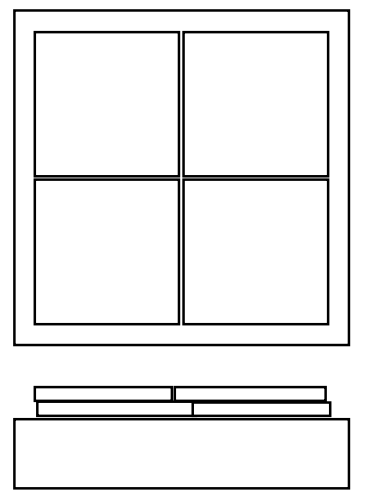

Figure 3 - "Interlocking" Tile Design Example

Subsequent refining of the design work on the interlocking tiles indicated that an overlapping, hexagonal shape would have the highest probability of success. This configuration has the advantages listed below and is shown in Figure 4.

- The hexagonal shape was believed to be the most "damage tolerant" of the studied shapes and would require multiple through cracks to enable an individual tile to be removed from its locked position. A square tile would only require one.

- The hex design also allows for better in plane connectivity and containment compared to a square tile. The hex would result in six (6) sequential "over/under" tabs, which would secure the tiles more than the four tabs a square shape would supply. 
- The hex shape would be more tolerant to out-of-plane movement (i.e., buckling) than the square shape as the neighboring tiles provide a hold down force that would prevent excess vertical tile movement.

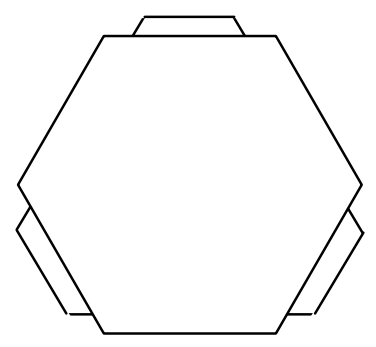

Top View

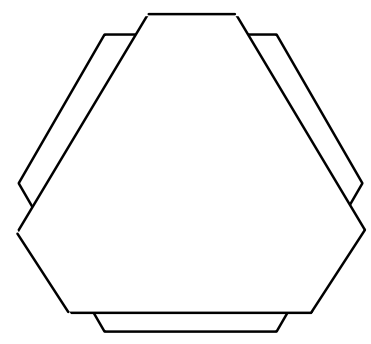

Bottom View

Figure 4 - Hexagonal Tile Design

\section{Tile Preparation and Installation for the First Pilot Cell}

Because of prior difficulty in distinguishing the best tile compositions in benchtop testing, a randomized test array of eight compositions was selected for testing in the first pilot cell operation. The selected compositions including representatives of $\mathrm{TiB}_{2}, \mathrm{TiB}_{2}+\mathrm{C}$ and $\mathrm{Ti}_{3} \mathrm{SiC}_{2}$ compositions, selected for prior performance, estimated fabrication cost and technical significance.

Once the materials and shape of the tiles were chosen, the optimum dimensions for the test tiles needed to be established. Given the coverage area of $60 \times 54.5$ " and the required eight (8) different materials in the test matrix, it was determined that each tile should be a regular hexagon with a face length of 3.5". A tile this size would not present any forming, handling or installation difficulties and would allow for a significant number of tiles from each composition to be tested. In this 3.5" hexagonal configuration, 115 tiles were required for PC1 (Figure 5). 


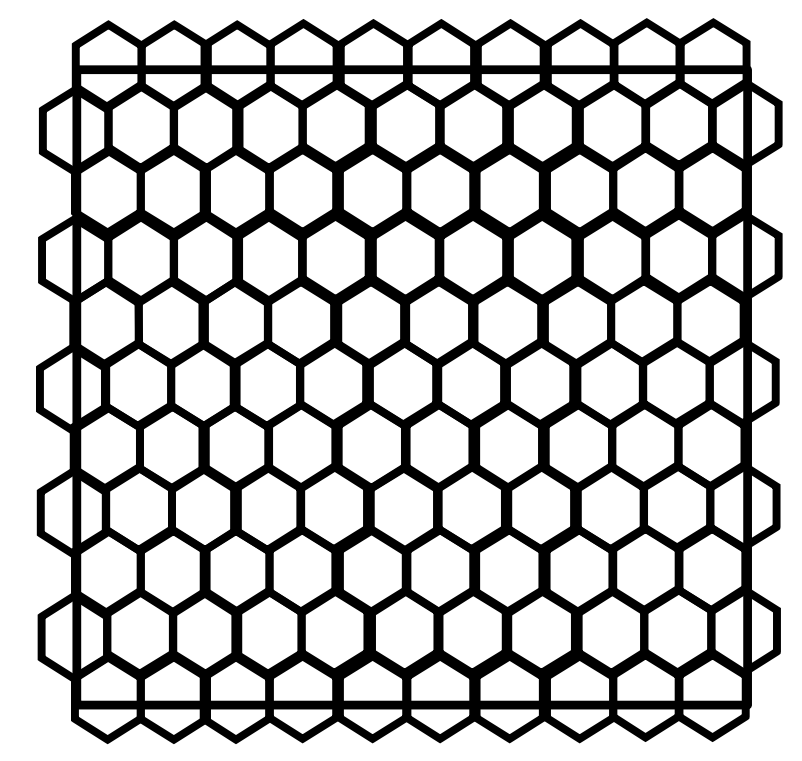

Drained Edge

Figure 5 - PC1 Hexagonal Tile Orientation

The next area of concern was the size and shape of the upper and lower tabs, which form the interlocking structure of the tiles. The tabs, it was determined, should be half the thickness of the tiles for ease in machining. This size would also supply enough strength to resist the expected lift/hold down forces placed on it by neighboring tiles (Figure 6). Once the design of the tiles for PC1 was completed, work began on the production of the tiles.

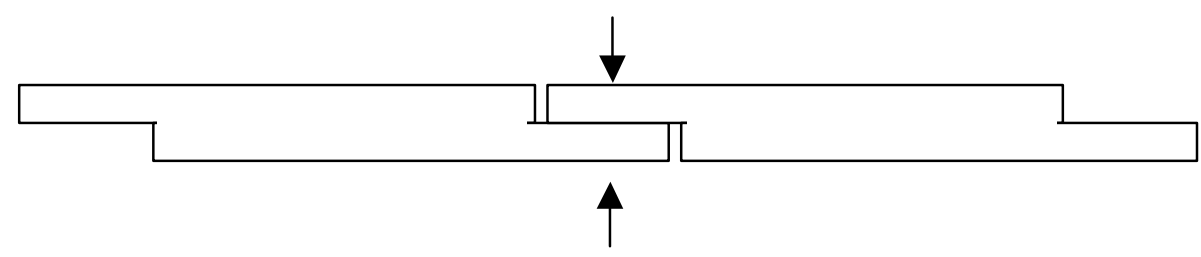

Figure 6 - Diagram of Hold Down Tabs on Tiles

The reaction sintered (RS) 312 tiles were produced using a direct reaction or "thermal explosion" method. This method uses the constituent powders for the final product (TiC, $\mathrm{SiC}$ and $\mathrm{C}$ ) pressed into the final shape required. This part is then placed in a furnace and heated along a specific profile to the reaction temperature. Once at the reaction temperature, a reaction wave moves quickly through the tile, converting the constituent powders into 312 . The resulting part is essentially all 312 and is ready for forming.

The dry pressed 312 and $\mathrm{TiB}_{2}+\mathrm{C}$ tiles were produced using traditional pressing methods. The given ceramic powders are mixed with a small amount of a binder material and placed into a steel mold. The powder is then pressed to a specific pressure, held at that pressure 
and then released. This is repeated several times; the tile is then removed from the die and allowed to dry. Finally, the tiles are sintered to increase density and impart strength.

The wet processed $\mathrm{TiB}_{2}+\mathrm{C}$ tiles were produced by a method similar to dry pressing, but using a higher water-content feed material. The excess water in the binder solution allows a more even (hydrostatic) pressure to be placed on the part, resulting in a more uniformly dense part. After pressing, the tile is removed from the die and oven dried to remove the remaining water. After drying, the tiles are sintered.

Once the tiles are sintered, they can be shaped. The tiles are cut to a rough hexagonal shape on a regular diamond tile saw and then shaped using a grinder.

During cell design discussions, a possibility was raised that the movement of the aluminum pad in the cell could move the tiles at the drained edge into the sump. If these tiles did slide into the sump, a chain reaction that could unzip the interlocking nature of the tiles could begin. Various options to prevent this unzipping were discussed and a decision was made to use a series of vertical plates to restrain the tiles.

\section{Tile Installation}

An ART representative attended the final stages of pilot cell construction to install the tiles. Once the cathode blocks were installed and the seams filled with carbon, the tiles could be installed. The individual tiles were installed by hand starting with the drained edge tile (Figure 7) and proceeded toward the rear of the cell by rows (Figure 8). 


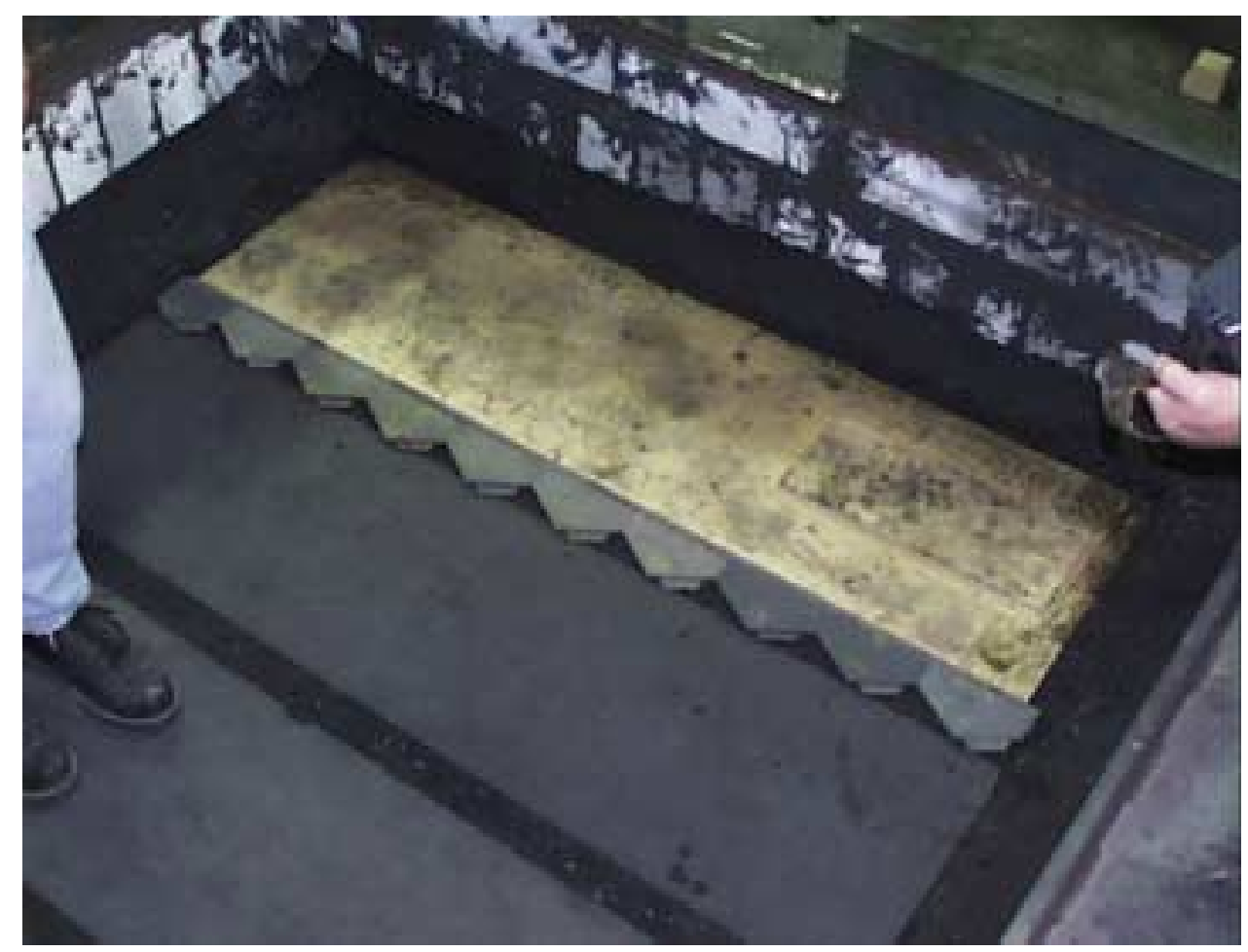

Figure 7 - Installation of Drained Edge Tiles

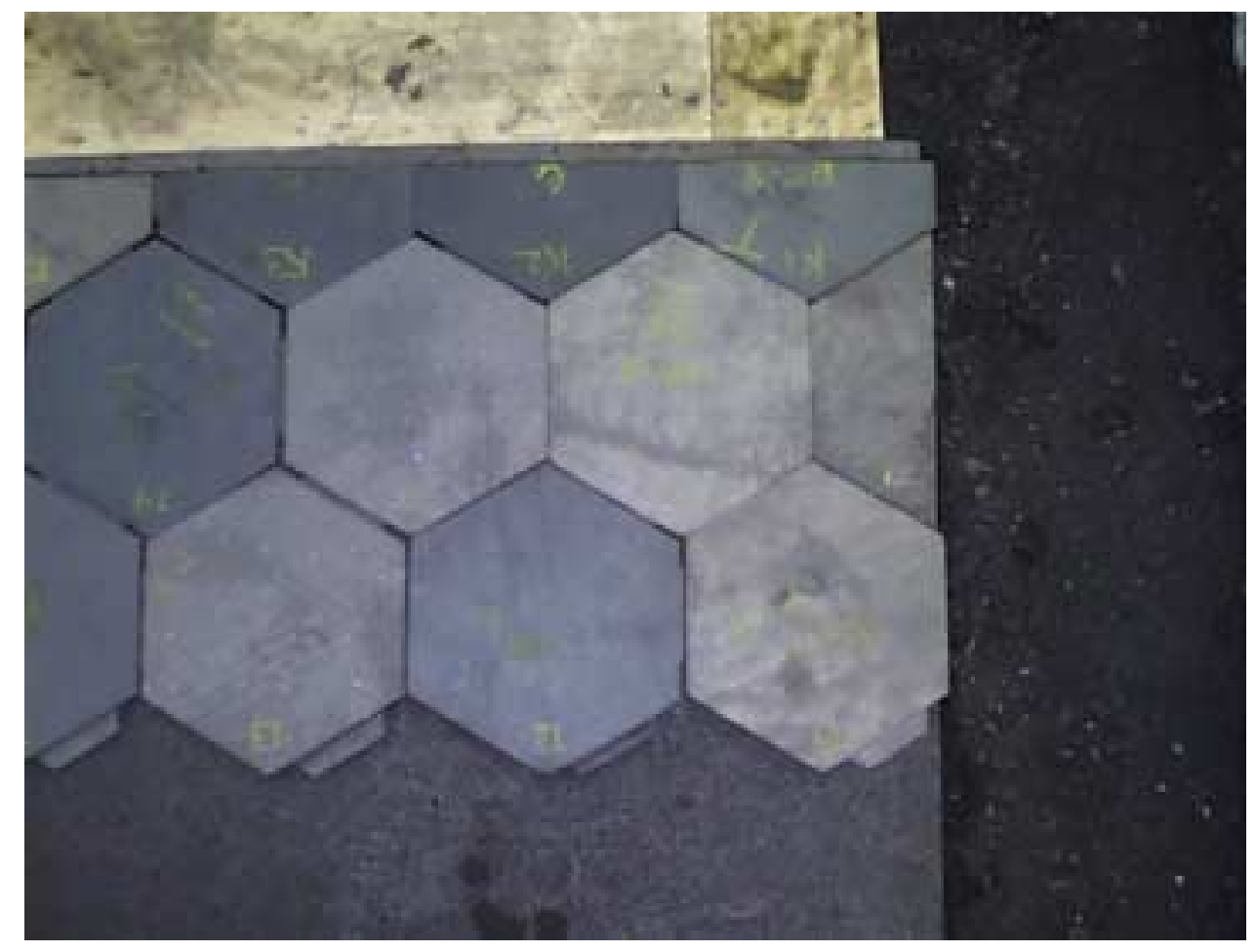

Figure 8 - Close View of Tile Gapping Near Left Side of Cell 
The final layout of the tiles included one tile from each composition along the drained and rear edges of the cell and a random placement of tiles from each composition in the field tiles. The final layout of the tiles and the location of the different compositions evaluated in this pilot cell are included in figures 9-10.

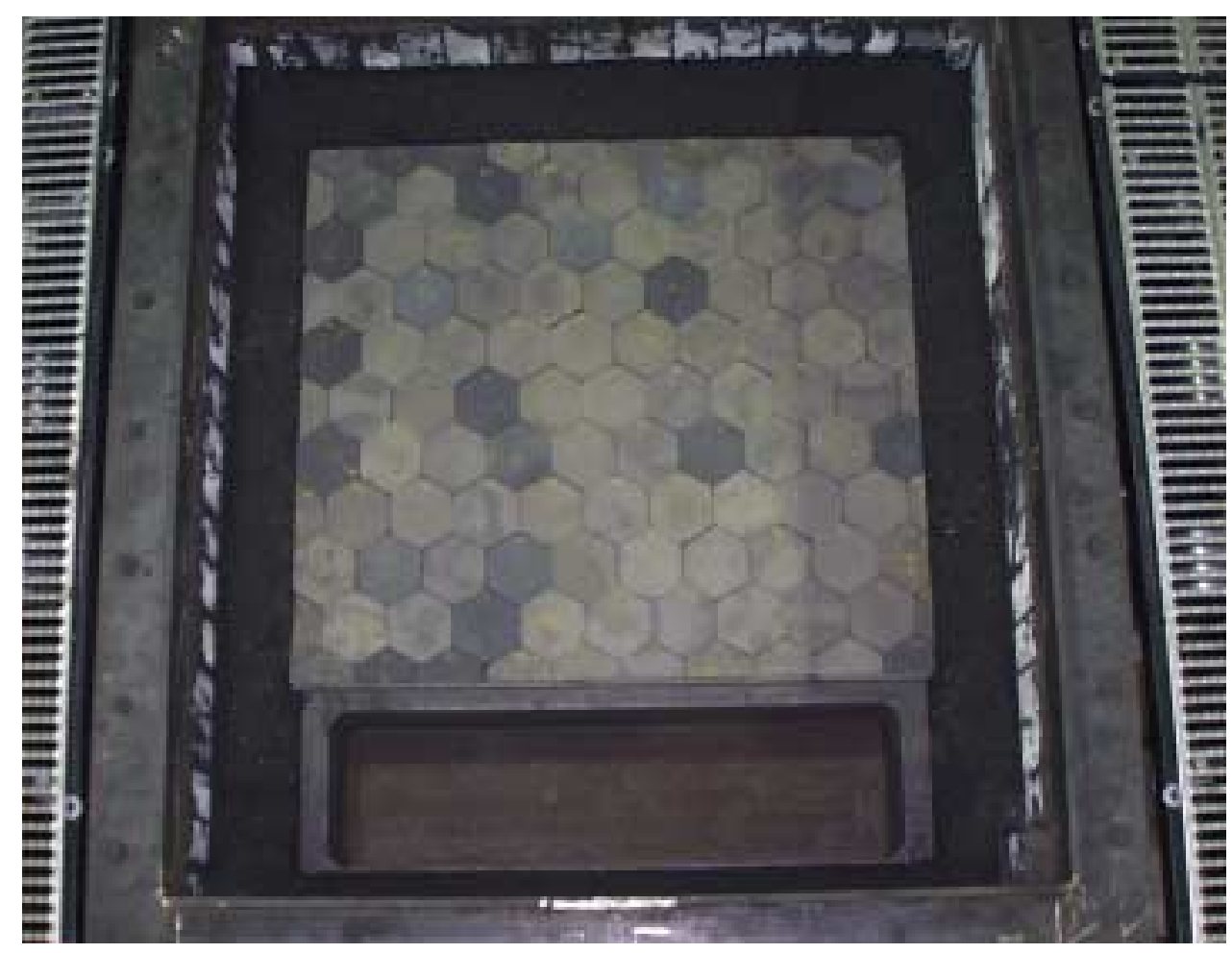

Figure 9 - Overview of Completed Tile Installation 


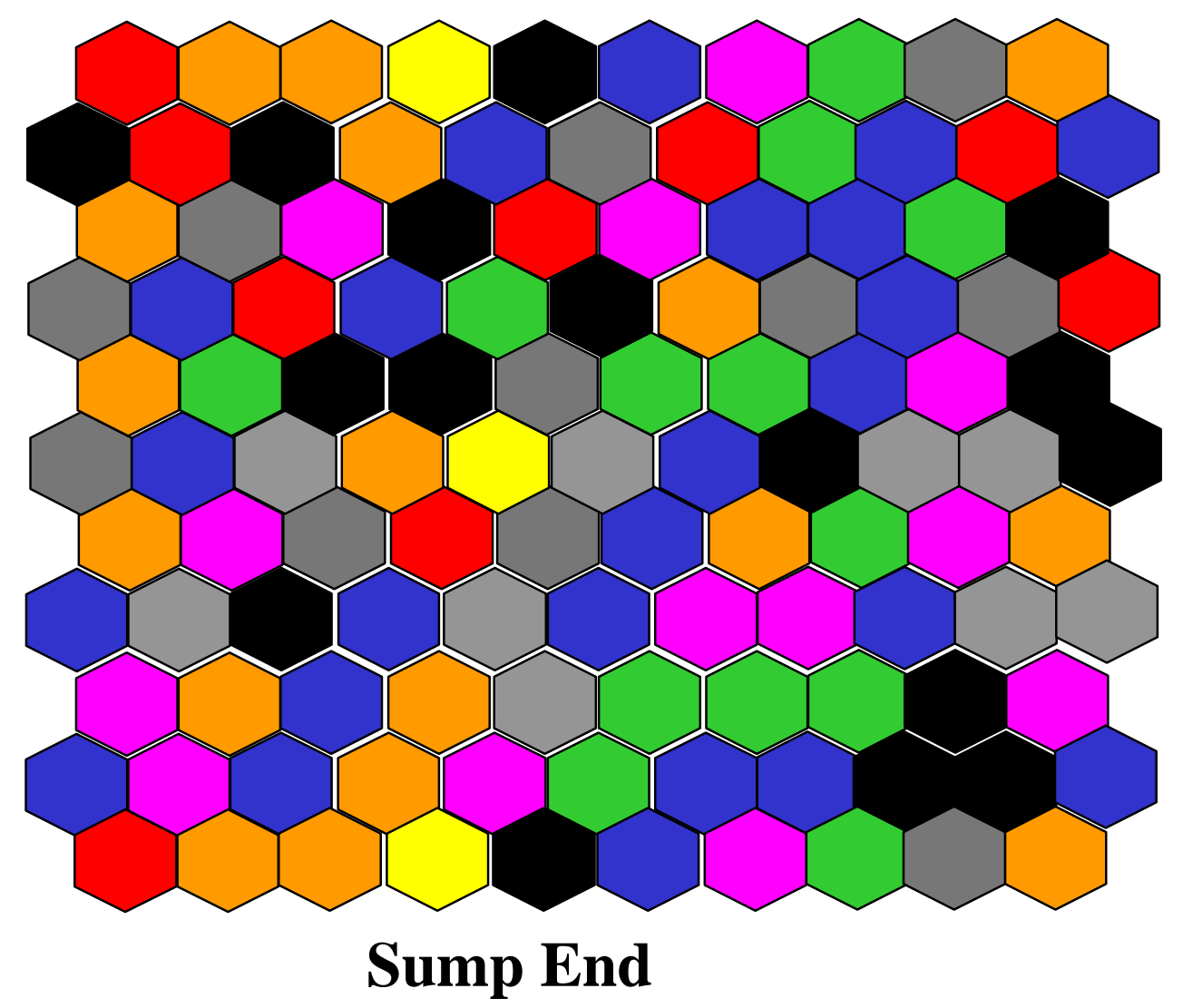

$\begin{array}{ll}\text { Color: } & \text { Materials: } \\ \text { Red: } & \mathrm{RS} \mathrm{Ti}_{3} \mathrm{SiC}_{2} \\ \text { Orange: } & \mathrm{DP} \mathrm{Ti}_{3} \mathrm{SiC}_{2} \\ \text { Yellow: } & \mathrm{WP} \mathrm{TiB}_{2} \\ \text { Green: } & \mathrm{DP} \mathrm{TiB}_{2}+\mathrm{C} \text { (High C) } \\ \text { Blue: } & \mathrm{WP} \mathrm{TiB}_{2}+\mathrm{C} \text { (High C) } \\ \text { Purple: } & \mathrm{DP} \mathrm{TiB}_{2}+\mathrm{C} \text { (Medium C) } \\ \text { Black: } & \mathrm{WP} \mathrm{TiB}_{2}+\mathrm{C} \text { (Medium C) } \\ \text { Gray: } & \mathrm{WP} \mathrm{TiB}_{2}+\mathrm{C} \text { (Low C) }\end{array}$

Figure 10 - Location of Candidate Materials in Test Cell

Given thermal expansion data on the individual materials, it was calculated that a 1/8" gap was needed between the tiles to allow for expansion at operating temperature. This gapping was accomplished during the installation by eye and then verified with the use of small plastic spacers. 


\section{Pilot Cell 1 Operation}

The pilot cell operations objectives were:

- Confirm optimum material composition and configuration

- Demonstrate operation at decreased ACD

- Confirm viability of end sump design

- Demonstrate operation with enhanced cathode package

- Develop operational procedures for industrial cell

The first pilot cell was operated for 21 days (from October 15 to November 5, 1999). Cell performance clearly showed that the ceramic cathode surface allowed for aluminum wetting as designed, and cell operations generally went smoothly. During operations, high Ti levels were observed in the recovered aluminum (Figure 11). This suggested that tile degradation was occurring in at least a portion of the tile array. Physical evaluation of the tile surface provided evidence that the tile surface was physically disrupted in some areas. Despite these observations, the cell operated well in both drained and metal pad modes. The metal pad mode was operating the cell in a conventional manner with approximately 2" of metal over the tiles; while, the drained mode the metal inventory was maintained in the sump only. Figure 12 illustrates these differences.

Upon cool down and disassembly, it was found that a wide range of tile performance occurred, linked primarily to composition. In general, $\mathrm{Ti}_{3} \mathrm{SiC}_{2}$ and "pure" $\mathrm{TiB}_{2}$ materials performed poorly. In some cases, tiles of these compositions were nearly gone from their locations by means of fracture and erosion. $\mathrm{TiB}_{2}-\mathrm{C}$ tiles fared better, with low carbon samples exhibiting the best performance. In most cases, tiles of this composition remained intact and generally unscathed from the test conditions. Fortunately, the restraint plates along the sump edge were made from this composition, and they generally showed good performance as well.

Microscopic examination of poor performing samples showed distinct dissolution and erosion of the material, presumably due to reactions with aluminum and/or bath. Material degradation generally occurred in a 2-step process. Chemical attack and dissolution occurs first, and targets high energy areas between grains. This leads to disruption of grain bonds and loss of material strength on the surface. Aluminum movement on the tile surface then sweeps the dislodged grains away from the tile and into the metal of the sump. This leads to the high Ti contents observed in the tapped metal, and the loss of poor performing tiles. $\mathrm{Ti}_{3} \mathrm{SiC}_{2}$ tiles, in particular, were nearly completely destroyed and missing from the cell. It was noted that this result was contrary to benchtop testing results, where 312 components routinely showed excellent performance. 
Titanium Level in Aluminum

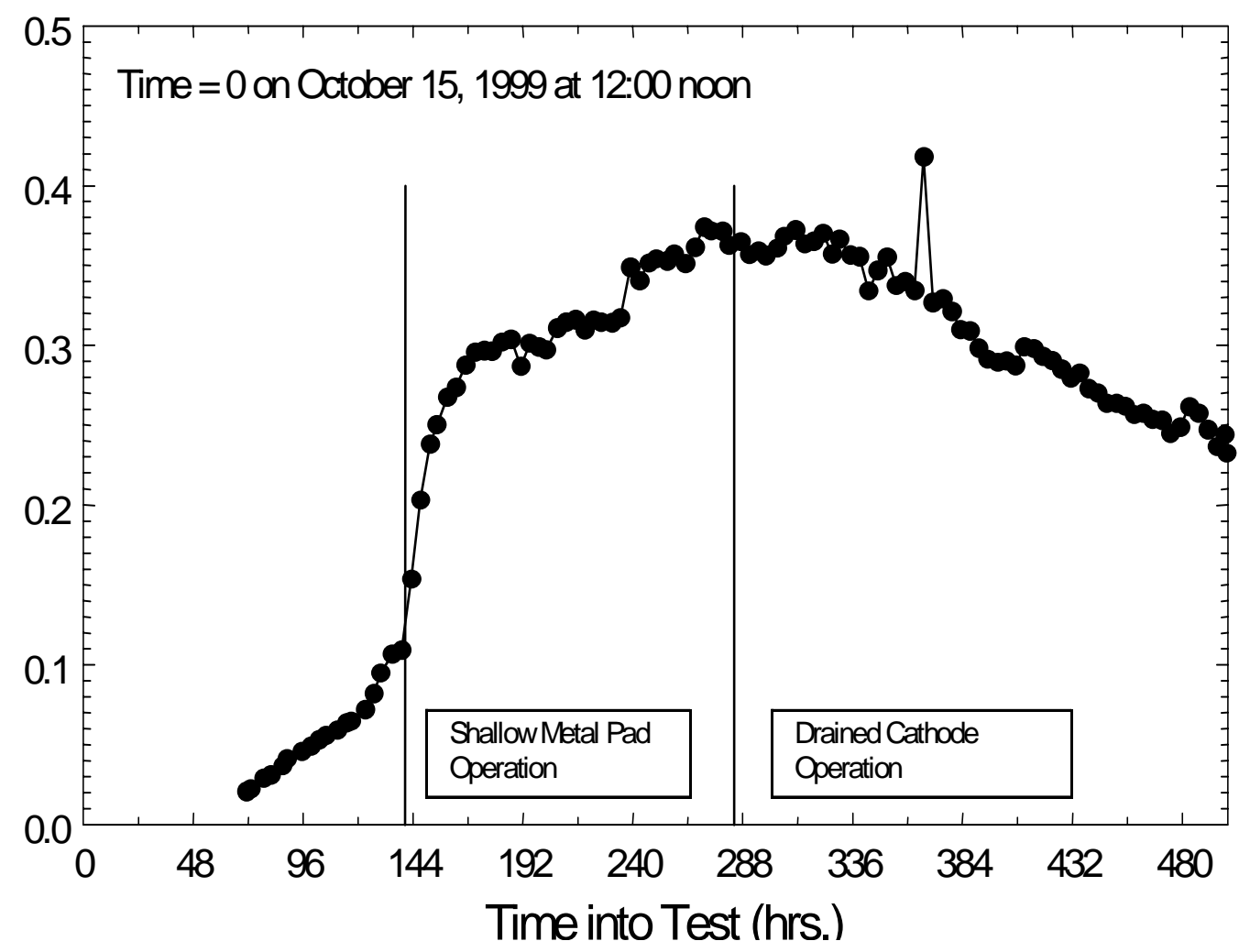

Figure 11 - Titanium Level in Metal During PC 1

Even in good performing tiles, aluminum penetration was observed in the samples at the microscopic level. This aluminum reacted with the carbon reinforcement to produce aluminum carbide. Subsequently, the aluminum carbide dissolved in the remaining molten aluminum over longer periods of time. In high carbon samples, this carbide formation reaction was disruptive, cracking the material due to volumetric expansion. Many of these samples were macroscopically cracked, and thus do not represent a suitable long-term material for the application. 


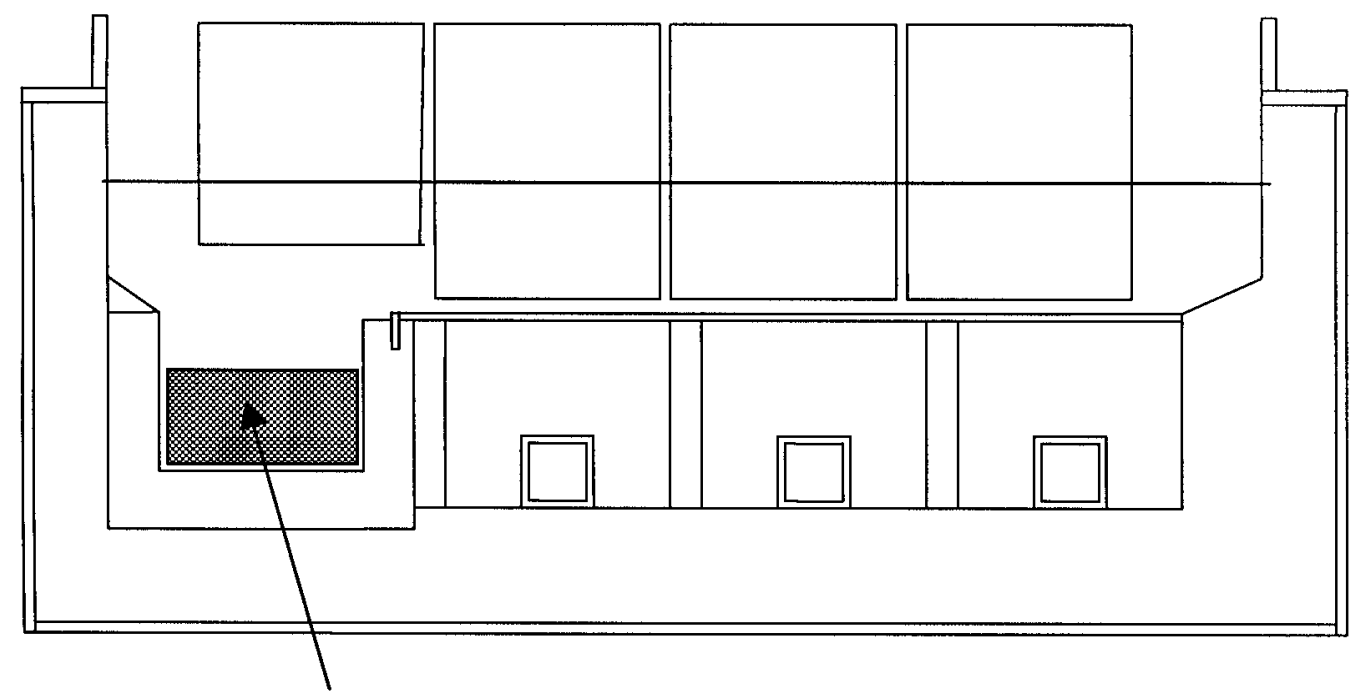

Drained Cell Operation - Metal Pad Contained in Sump

Shallow Metal Pad Operation - Metal Pad over Tiles and Sump

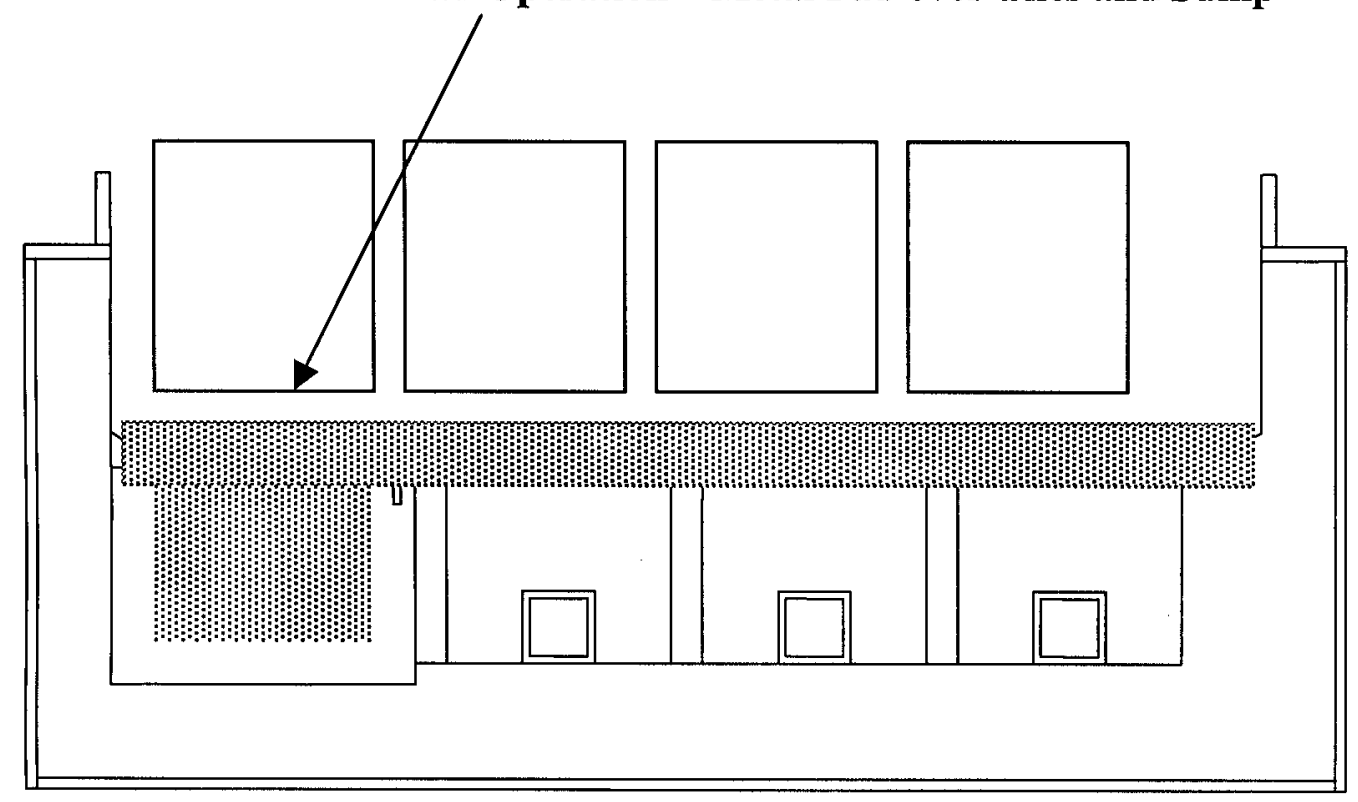

Figure 12 - Drained versus Metal Pad Operation 
Lower carbon samples fared better, exhibiting little to no cracking. The aluminum reactions appear to have no other negative effects, and it is noted that the addition of aluminum in the porosity likely improves the electrical and thermal conductivity of the wetted cathode surface. The below table summarizes the results of the various compositions in the cell.

\section{Table I - Summary of Tile Survivability - Pilot Cell 1}

\begin{tabular}{|c|c|c|c|c|}
\hline Material & $\begin{array}{c}\text { Undamaged } \\
\text { Tiles }\end{array}$ & Damaged Tiles & Missing Tiles & $\begin{array}{c}\text { Calculated \% } \\
\text { Weight Loss }\end{array}$ \\
\hline $\begin{array}{c}\text { WP TiB2+C } \\
\text { (Low C) }\end{array}$ & 18 & 2 & 0 & 0.1 \\
\hline $\begin{array}{c}\text { WP TiB2+C } \\
\text { (Medium C) }\end{array}$ & 13 & 3 & 0 & 0.7 \\
\hline $\begin{array}{c}\text { WP TiB2+C } \\
\text { (High C) }\end{array}$ & $\mathbf{9}$ & 3 & 1 & 3.2 \\
\hline $\begin{array}{c}\text { DP TiB2+C } \\
\text { (Medium C) }\end{array}$ & 13 & 3 & 0 & 4.6 \\
\hline $\begin{array}{c}\text { DP TiB2+C } \\
\text { (High C) }\end{array}$ & 7 & 6 & 0 & 4.6 \\
\hline WP TiB2 & 0 & 7 & 10 & $\mathbf{2 4 . 1}$ \\
\hline DP 312 & 0 & 4 & 5 & 81.0 \\
\hline RS 312 & 0 & 0 & 0.0 & \\
\hline
\end{tabular}

Despite the failure of a significant number of the ceramic tiles, a number of important conclusions were seen about operating the cell in a drained cathode configuration.

i) The pilot cell ran equally stable during shallow metal pad operation and drained operation.

The pilot cell was able to operate during both modes of operation as a result of the wettable cathode surface provided by the tiles covering the cathode blocks.

ii) No noticeable instabilities developed during the transition of the pilot cell from shallow metal pad operation to drained operation.

The transition from shallow metal pad operation to drained operation occurred in two different ways: as the metal level fell into the sump as a result of tapping, and as the metal level rose above the sump as a result of production.

iii) The ACD during drained operation was as tight as 0.5 inches in some locations. 
Tile damage made it impossible to assign a single value to the ACD during drained operation. However, there were locations around the perimeters of the anodes where the ACD was as tight as 0.5 inches. The ACD during shallow metal pad operation was on the order of 1.5 inches.

iv) The only effective method of extinguishing anode effects during drained operation involved the momentary interruption of power to the cell.

Conventional methods of extinguishing anode effects were not effective on a drained cathode cell. Such methods make use of the metal pad to short against the anodes, but a drained cell has no metal pad other than the metal in the sump. All attempts to use the metal in the sump to extinguish anode effects in the pilot cell failed; as did the attempt to pump the anodes while feeding and the attempt to increase bath circulation by inserting a green pole down the center aisle.

That power to the cell had to be interrupted in order to extinguish an anode effect, in itself, presents a significant obstacle to the commercial implementation of drained cathode technologies. A means of extinguishing anode effects other than shutting off the power to the cell must be developed.

v) The sump worked as designed; an excessive amount of ledge did not form on its interior walls.

Prior to start-up of the cell, there was much concern regarding the consequences of too much ledge forming in the sump. Fortunately, the interior of the sump remained clear enough to allow entry of the tapping spout and accommodate a day's production of metal.

vi) All cathodic carbon and graphite surfaces exposed to electrolysis were eroded.

Three areas of the cathode were prone to erosion: the ram-paste toe around the perimeter of the cathode, the exposed surfaces of the graphite cathode blocks, and the exposed surfaces of the graphite sump.

The ram-paste toe was not protected by metal during drained operation and very little of it remained by the end of the test. The tile coverage extended to the edges of the cathode blocks and the ram-paste was used to fill the spaces between the cathode blocks and the silicon carbide brick. Therefore, the toe was directly exposed to electrolysis during drained operation.

Areas of the cathode blocks that lost tile coverage during the test were also highly eroded. Some tiles dissolved away, others broke into pieces, and several shifted positions. The degree of erosion varied; it was assumed that the degree of erosion was related to the length of time the surface was exposed. 
Erosion of the sump was most severe along the upper edges closest to anodes 4 and 5. The edge of the sump along the retaining tiles was almost eroded all the way to the retaining tiles. It appeared that had the cell been operated much longer, the retaining tiles would have eventually lost their integrity and fallen into the sump.

In this regard, the design of the pilot cell was not robust enough to sustain prolonged operation. A robust cell design cannot permit its cathodic carbon surfaces to become exposed to electrolysis. Once a carbon surface becomes the active cathode surface in an aluminum reduction cell, it immediately begins to erode away as a result of the formation of aluminum carbide $\left(\mathrm{Al}_{4} \mathrm{C}_{3}\right)$.

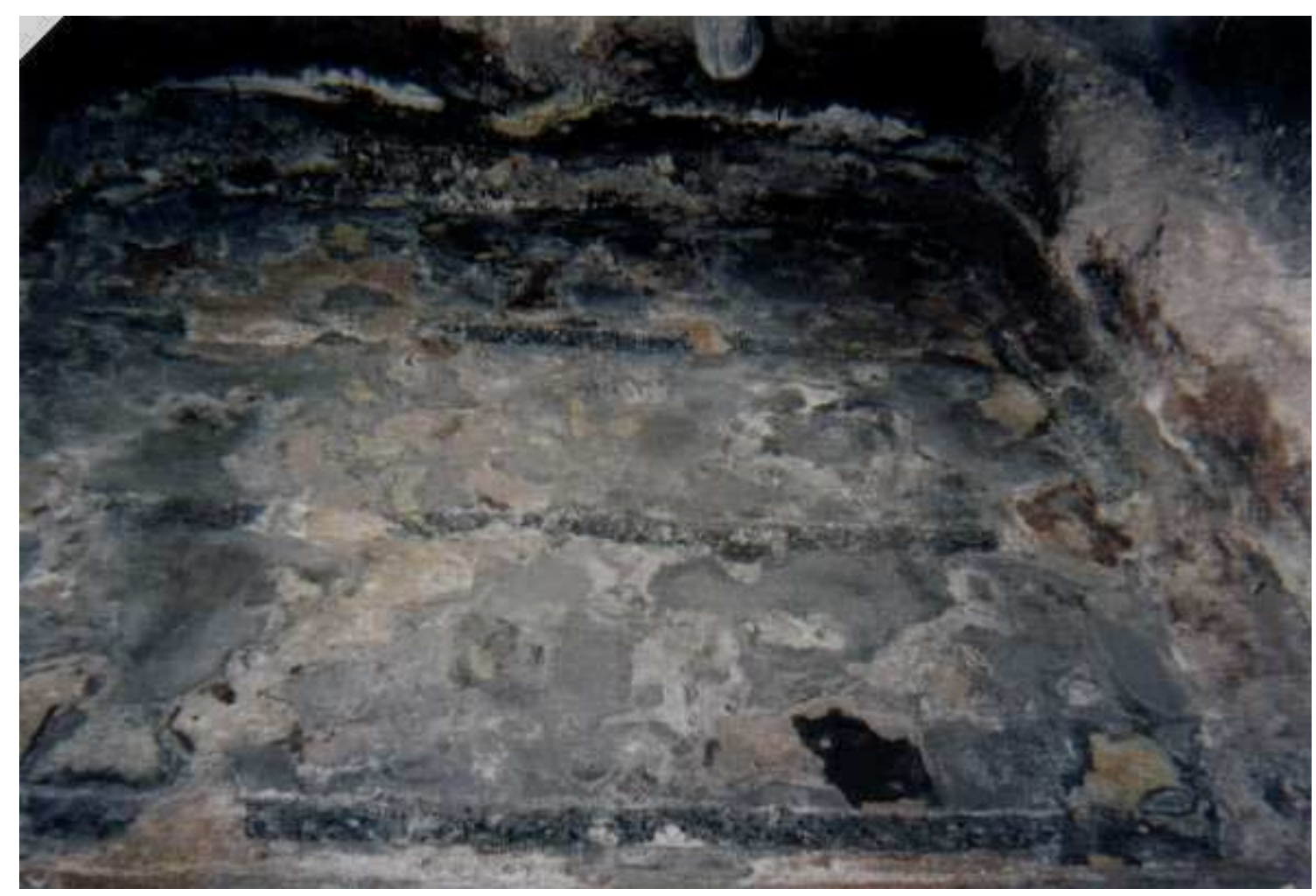

Figure 13 - Pilot Cell 1 Showing Erosion of Cathode and Rammed Toe

\section{Pilot Cell 2 Operation}

The second pilot cell operation had several primary objectives. These were:

- Confirm the optimum material composition and configuration

- Demonstrate operation at an anode-to-tile distance of one inch

- Confirm the viability of the end sump design

- Demonstrate operation with enhanced cathode package, and

- Develop operational procedures for the industrial cell 
Overall the pilot cell operation was very successful in addressing these objectives. Not all were accomplished, but significant direction was provided for the industrial cell operation. More detailed discussion of each of these will be discussed in the following sections.

\section{$\underline{\text { Tile Material Composition and Configuration }}$}

The pilot cell had tiles of the $\mathrm{TiB}_{2}-\mathrm{C}$ (low carbon content) composition, which from the first pilot cell proved to be the most durable. This operation confirmed that observation, both from physical observation after the run and the titanium levels during the operation. The titanium levels in the metal were only slightly above normal background levels (.0055\% - Figure 12). Nearly all tiles looked undamaged, with most surfaces and edges remaining sharp and distinct after the operation. The only missing tiles were those associated with the failure at the edge of the sump. The interlocking, hexagonal layout proved to provide a robust method in which to install the tiles.

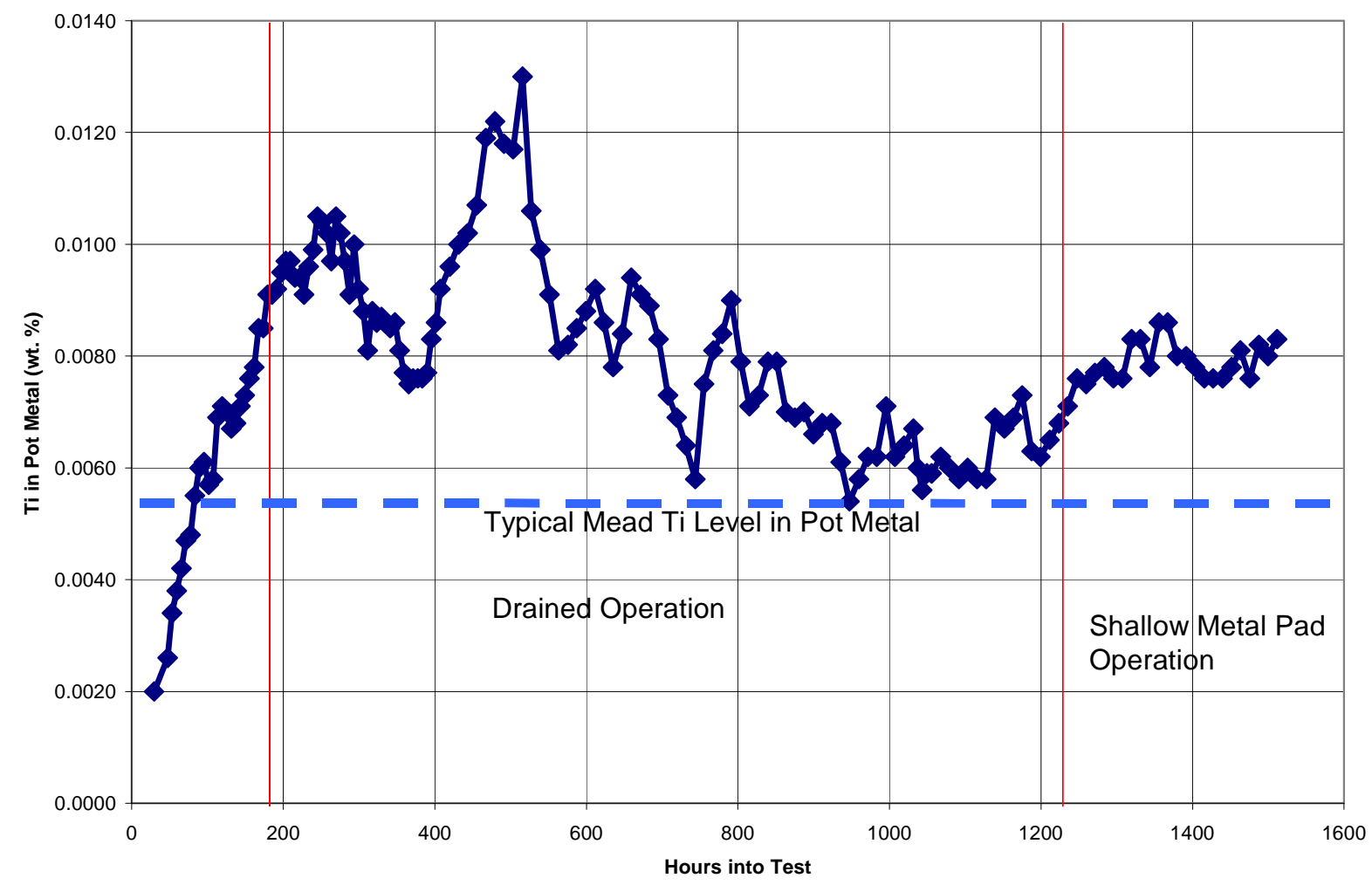

Figure 14 - Titanium Levels in the Metal During PC 2 


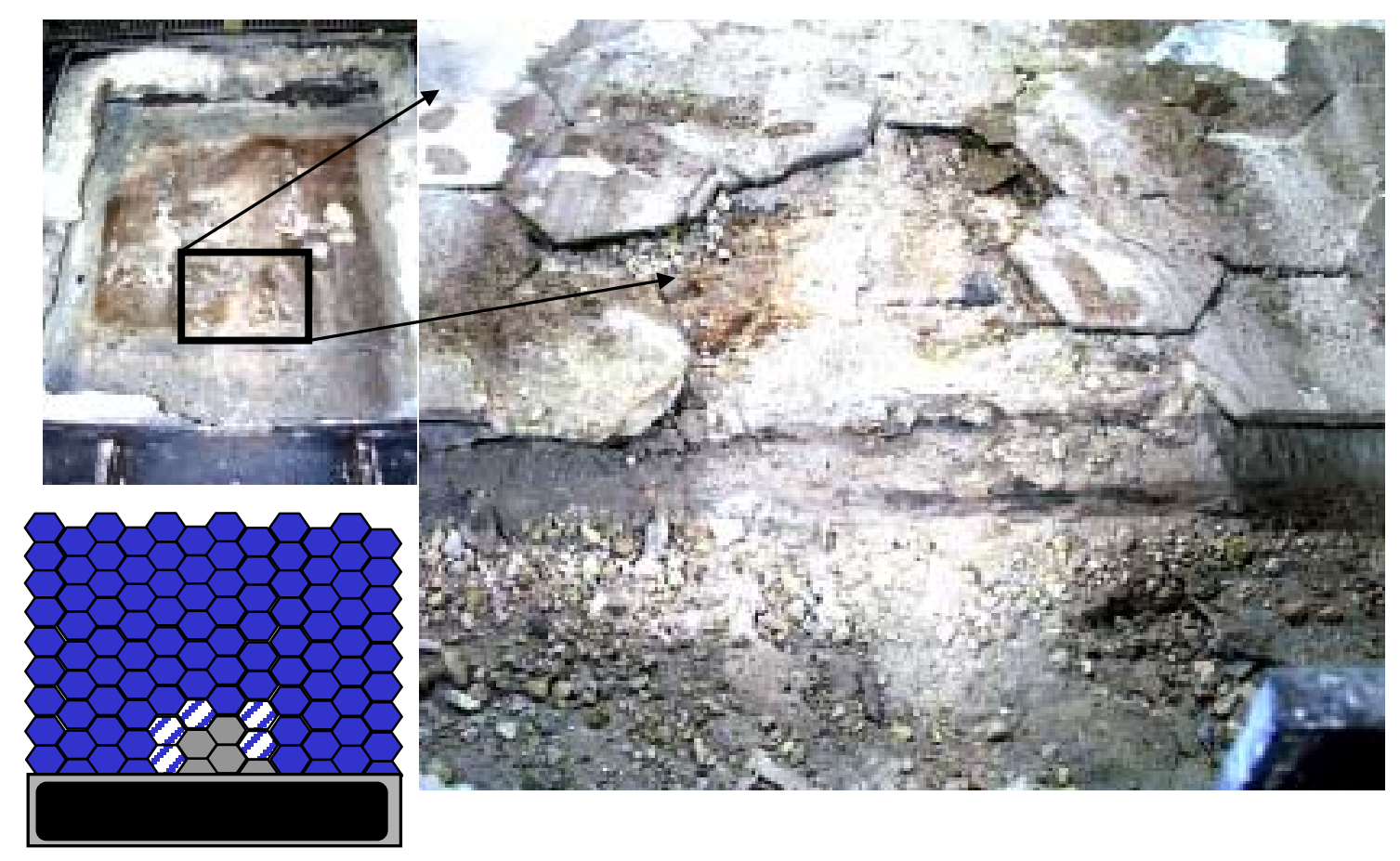

Figure 15 - Pilot Cell 2 Post Operation Tile Condition

\section{Operational Performance}

The pilot cell operated very stable in all modes of operation evaluated. Routine operations of anode changing, metal tapping, and bridge raising were not issues. During the drained operation, metal tap resulted in about a 0.2 -volt increase due to the anodes over the sump carrying reduced load with tap. This effect would be expected to be much less with an industrial cell operation.

Also, during drained operation problems did develop with carbon dirt formation from the two anodes over the sump. This was a result of the anodes being at low current density and not well protected. Procedures were developed to routinely splash the anodes with bath to help protect the air burning. This helped to alleviate the problem.

The cell was able to operate without sludge accumulation in the sump. At times sludge did develop, but with the tapping of the metal from the sump it was quickly dissipated.

Operation was routinely maintained with anode-to-tile distance of 1.3 inch $(3.3 \mathrm{~cm})$ and demonstrated periods of less than one inch $(2.5 \mathrm{~cm})$. Thermal considerations (low superheat due to insulation being compromised due to metal leak during startup) prevented extended periods at this reduced anode-to-tile distance. Measured values for current efficiency for both modes of operation were inconclusive, and will have to be fully evaluated in industrial testing. Current efficiency was measured in two methods: by weighing metal tapped and by use of a silver dilution technique. Results of these two methods for the two modes of operation are summarized below. 


\begin{tabular}{|l|l|l|}
\hline & $\begin{array}{l}\text { Shallow Metal Pad } \\
\text { Operation }\end{array}$ & $\begin{array}{l}\text { Drained Metal Pad } \\
\text { Operation }\end{array}$ \\
\hline Weighed Metal Tap & $90.2 \%$ & $88.6 \%$ \\
\hline Silver Dilution & $91.5 \%$ & $90.4 \%$ \\
\hline
\end{tabular}

The cell's current efficiency was influenced negatively due to the bath chemistry selected, operating temperatures obtained, extensive cell disturbances due to special measurements and carbon dirt present. The major objective of the testing was to prove the drained concept and materials and not to optimize current efficiency; however, this must be answered to fully evaluate this technology. This would become of increased importance in commercial cell testing.

Overall the operation was very smooth and showed good promise leading into an industrial cell test. The below table summarizes the key parameters from both of the pilot cell operations.

Table II - Summary of Pilot Cell Performance

\begin{tabular}{|l|c|c|c|c|}
\hline & \multicolumn{2}{|c|}{ Pilot Cell 1 } & \multicolumn{2}{c|}{ Pilot Cell 2 } \\
& $\begin{array}{c}\text { Shallow } \\
\text { Metal } \\
\text { Pad }\end{array}$ & $\begin{array}{c}\text { Drained } \\
\text { Cathode } \\
\text { Operation }\end{array}$ & $\begin{array}{c}\text { Drained } \\
\text { Cathode } \\
\text { Operation }\end{array}$ & $\begin{array}{c}\text { Shallow } \\
\text { Metal } \\
\text { Pad }\end{array}$ \\
\hline Duration, days & 6.7 & 9.2 & 43 & 12 \\
\hline Current, kA & 23.02 & 22.70 & 23.53 & 23.82 \\
\hline Voltage & $\mathbf{4 . 8 6}$ & $\mathbf{4 . 6 2}$ & $\mathbf{5 . 1 9}$ & $\mathbf{5 . 5 9}$ \\
\hline Stability & .051 & .037 & .027 & .025 \\
\hline Temp, Deg C & 968.0 & 974.8 & 974.3 & 967.8 \\
\hline Superheat & 14.9 & 20.7 & 15.3 & 9.1 \\
\hline Ti in Metal, \% & $\mathbf{. 2 8 3 7}$ & $\mathbf{. 3 0 6 8}$ & $\mathbf{. 0 0 8 0}$ & $\mathbf{. 0 0 7 8}$ \\
\hline $\mathrm{Bath}_{\mathrm{Catio}}$ & 1.17 & 1.20 & 1.19 & 1.19 \\
\hline $\mathrm{CaF}_{2}, \%$ & 4.39 & 4.83 & 4.28 & 4.46 \\
\hline $\mathrm{MgF}_{2}, \%$ & 0.98 & 0.76 & 0.49 & 0.50 \\
\hline $\mathrm{LiF}_{2} \%$ & 0.54 & 0.55 & 0.47 & 0.45 \\
\hline $\mathrm{Al}_{2} \mathrm{O}_{3}, \%$ & 2.95 & 3.43 & 3.41 & 3.03 \\
\hline
\end{tabular}

\section{Viability of End Sump Design}

The end sump design was of great concern going into the pilot cell operations, but following the testing it appears to be much less of a concern. The concept proved to work well. Sludge formation did not prove to be an issue. The issue that did develop, which must be addressed before proceeding further, is that of erosion of the exposed carbon of the sump. Due to the repetitive exposure to aluminum and then bath, significant erosion of the sump does occur, thus causing failure of the restraining mechanism used for the tiles. 
Figure 16 shows the cross section of the sump following the operation. The walls were initially the same thickness at the top of the sidewall as the bottom.

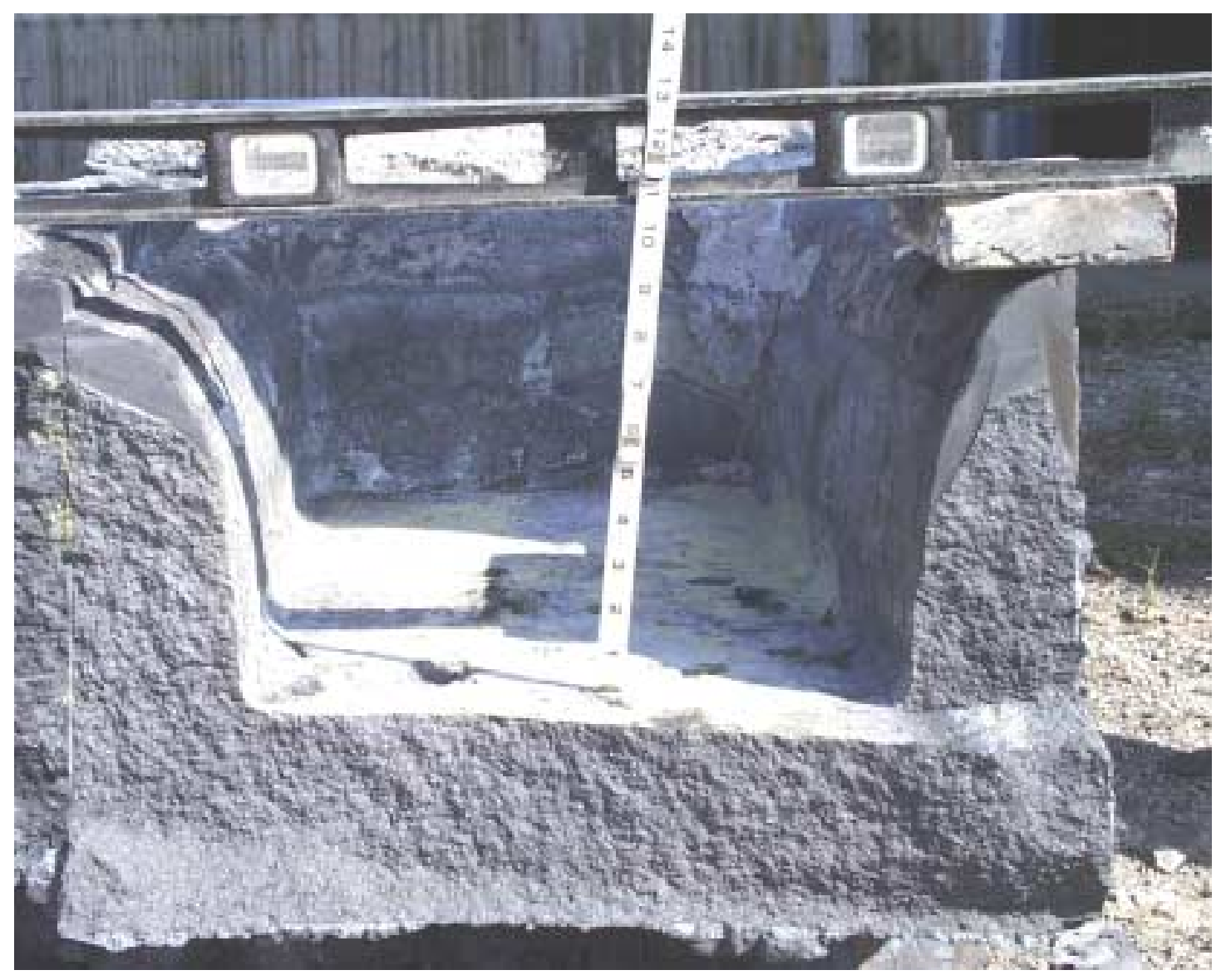

Figure 16 - Cross-section of End Sump Showing Wall Erosion

\section{Thermal Design}

The pilot cell showed significant sidewall and endwall erosion indicating extensive periods of operation with no protective ledge. This was in contrast to the first pilot cell operation in which the sidewalls were not attacked. The only significant change in the design was the use of a steel plate between the silicon carbide sidewall and the insulation to provide better protection of the insulation from bath penetration and the reduction of the calcium silicate insulation in the endwall from 2.5 " to 1.5 " to provide better ledge formation in the endwalls. Despite the improved protection of the insulation, increased heat losses were measured from the cathode (see below), probably influenced negatively by the metal leak which occurred during cell bake out. This increased heat loss required operating at elevated voltage (energy input) to maintain the target superheat $\left(15^{\circ} \mathrm{C}\right)$. The table below summarizes the heat loss measured during each of the pilot cell operations as well as operational data measured during the thermal studies. 


\begin{tabular}{|l|c|c|c|}
\hline & Pilot Cell 1 & Pilot Cell 2 & \\
\hline & $\mathrm{KW}$ & $\mathrm{KW}$ & \% Change \\
\hline North Side & 10.5 & 12.7 & 21.0 \\
\hline South Side & 8.0 & 8.8 & 10.0 \\
\hline Duct End & 4.1 & 8.1 & 97.6 \\
\hline Tap End & 6.4 & 9.3 & 45.3 \\
\hline Bottom & 5.0 & 5.1 & 2.0 \\
\hline & & & \\
\hline Total Cathode & 34.0 & 44.0 & 29.4 \\
\hline
\end{tabular}

\begin{tabular}{|l|c|c|c|}
\hline & Pilot Cell 1 & Pilot Cell 2 & Pilot Cell 2 \\
\hline & & $\begin{array}{c}\text { (During } \\
\text { Thermal } \\
\text { Study) }\end{array}$ & $\begin{array}{c}\text { (Average } \\
\text { Conditions) }\end{array}$ \\
\hline Voltage & 4.65 & 4.75 & 5.20 \\
\hline Amperage, kA & 23.1 & 23.8 & 23.8 \\
\hline Anode Drop, volt & .365 & .390 & .390 \\
\hline Cathode Drop, volt & .385 & .390 & .390 \\
\hline $\begin{array}{l}\text { Anode-Tiles Distance, } \\
\text { Active Anodes, inch }\end{array}$ & 1.00 & .875 & 1.3 \\
\hline $\begin{array}{l}\text { Anode-Tiles Distance, } \\
\text { Over Sump, inch }\end{array}$ & 4.00 & 3.55 & 4.00 \\
\hline
\end{tabular}

\section{Operational Procedures}

Most of the techniques required for an industrial cell operation have been demonstrated through operation of the pilot cell with the major exception of extinguishing anode effects. The pilot cell was unique in that the rectification had a 15 volt limit, thus at an anode effect the voltage peaked at 15 volts and the current dropped to zero. Thus, true simulation of what would be experienced in the industrial operation did not occur. The method used to extinguish the anode effect in the pilot cell consisted of turning the rectifier off, thus relieving the polarization and then restarting the rectifier. Alumina was also fed into the cell to bring the alumina content in the bath above the concentration which initiated the anode effect. This method is not considered practical in an industrial environment, as it would mean dropping the current on all the cells in the pot line. Primary direction will be first to minimize the number of anode effects. Other methods for extinguishing anode effects will have to be explored in the industrial test. 


\section{Industrial Cell Design}

\section{$\underline{\text { Basic Design Philosophy }}$}

The basic design philosophy was to make the overall cell design close to the design existing at the Kaiser Mead plant to make retrofitting into the plant as cost - effective as possible. In order to get the most applicable information from the pilot cell, its design would mimic the full sized industrial cell as much as possible.

Cell design issues to be overcome: The design of an energy conserving drained cathode cell presented unique challenges beyond those usually encountered in normal aluminum reduction cell design. These can be generally grouped into thermal, magnetohydrodynamic and physical issues.

\section{Thermal issues}

a. The energy conservation target for the project requires operation at $2.5 \mathrm{~cm}$ anode cathode distance (ACD) versus normal of around $4.5 \mathrm{~cm}$ for Mead plant. If the line amperage is not changed, this results in a proportionally low heat loss target which is outside the range of normal experience. The lining design must use materials and material arrangements which have not been proven in plant use.

b. Design with no metal pad presented unique challenges. The metal pad of a normal reduction cell is a very good conductor of heat, and the existing thermal model is calibrated for this effect. The reliability of the thermal model in the absence of the metal pad was unknown.

c. Effect of tiles or coating on cathode overvoltage was unknown. Heat is generated as a result of the chemical reaction at the cathode surface. When this is changed from the metal pad to a wetted $\mathrm{TiB}_{2}$ surface, the amount of heat generated could be changed, introducing inaccuracy into the thermal calculations.

d. End sump concept

1) The lack of an active anode above the end sump would increase the tendency to freeze. A special insulation package was developed for this area.

2) Reduced number of anodes increases the current density in remainder of the cell.

2. Magnetohydrodynamics issues

a. Effect of no metal pad except in sump area was an unknown. The whole purpose of the project was to operate a cell without a metal pad so as to generate no instability. The effect of the magnetic forces on metal in the sump was not expected to be a problem, but it was an unknown.

b. The effects of reduced ACD and the absence of metal pool on $\mathrm{CO}_{2}$ bubble release and bath circulation were unknown. Previous investigations had indicated that release of bubbles might be slower than normal when ACD is reduced. Bath circulation, which is critical to alumina solubility, is normally influenced by both metal pad movement and bubble release. Therefore the potential for reduced alumina solution rate and subsequent muck formation was present. 


\section{Physical issues}

a. Size, shape and location of sump were key design issues. The sump had to be sized big enough so that the metal tapping frequency was reasonable but small enough to minimize the need for special insulating technology.

b. Would there be enough space to install sufficient insulation without enlarging the shell or reducing the size of the anodes was also an issue.

c. Deformation of cathode surface due to thermal expansion and penetration by salts was a big unknown. Movement of several centimeters has been documented in conventional cells. With a conventional metal pad, these movements do not necessarily create a problem, but the effect on tiles or coatings as contemplated in this project was unknown.

With these design objectives and challenges, the design team, consisting of personnel from all three companies had numerous meetings starting in the early stages of the project. The design process was as follows.

1. Design industrial cell.

2. Design pilot cell to mimic as many of the features of the industrial cell as possible while still acting as appropriate test bed for material compositions and installation techniques.

3. Use performance and cell autopsy data from first pilot cell (PC 1) to design second pilot cell (PC 2).

4. Use performance and cell autopsy data from PC 2 to redesign the industrial cell.

\section{Design Process Description}

\section{$\underline{\text { Industrial Cell Design }}$}

1. Sump conceptual design criteria:

a. Simplicity: the simplest kind of sump was thought to be an end sump with no accompanying center trench. If it worked, it would allow the cathode surface to be constructed by conventional methods and minimize the changes needed to adapt the design for plant retrofit.

b. Metal capacity which dictates tapping frequency: replacement of one cathode block with a hollowed out "bathtub" would provide approximately 10 hours capacity for the industrial cell and about 30 hours for the pilot cell.

c. Thermal properties: since the sump was to be located away from the electrolysis reaction zone, it would have the tendency to freeze. Special consideration was thus given to insulation around the sump area including a lid to keep heat from escaping to the top. 
2. Thermal design

a. Setting the heat loss target: Kaiser's Cell performance model was used to calculate the heat loss target given the line amperage and ACD target (See Table III, "TiB Cell Parameter Estimate").

b. Thermal modeling: Kaiser's proprietary thermal model was used to simulate heat loss and ledge shape for various design options and sensitivities. Figure 17 is a representative thermal model output. Some of the options studied were:

1) Insulation material, thickness and placement

2) Cathode block material options (degree of graphitization)

3) Collector bar shape

4) Top crust and sump lid configuration

5) Liquid level variation in sump

6) Sensitivity to heat transfer coefficient assumptions since some were different from operating experience

7) Sensitivity to bath superheat variability (meant to simulate operational variability)

c. Design Process:

1) Model Mead standard cell for which heat losses are known

2) Model Mead standard cell with no metal pad and target ACD but no sump

3) Model end-sump cell

4) Model cases as described above to optimize insulation package and define sensitivities

d. Result: A thermal design package that predicted adequate ledge protection of the cell sidewalls while maintaining the sump at least $2 / 3$ free of ledge when the cell is operated at superheat of between 10 and 15 degrees Celsius.

3. Magnetohydrodynamic modeling: Kaiser's proprietary model was used to predict bath flow patterns resulting from removal of the tap-end anodes as well as low ACD. Some changes were predicted, but none were judged detrimental to the operation or robustness of the cell. 


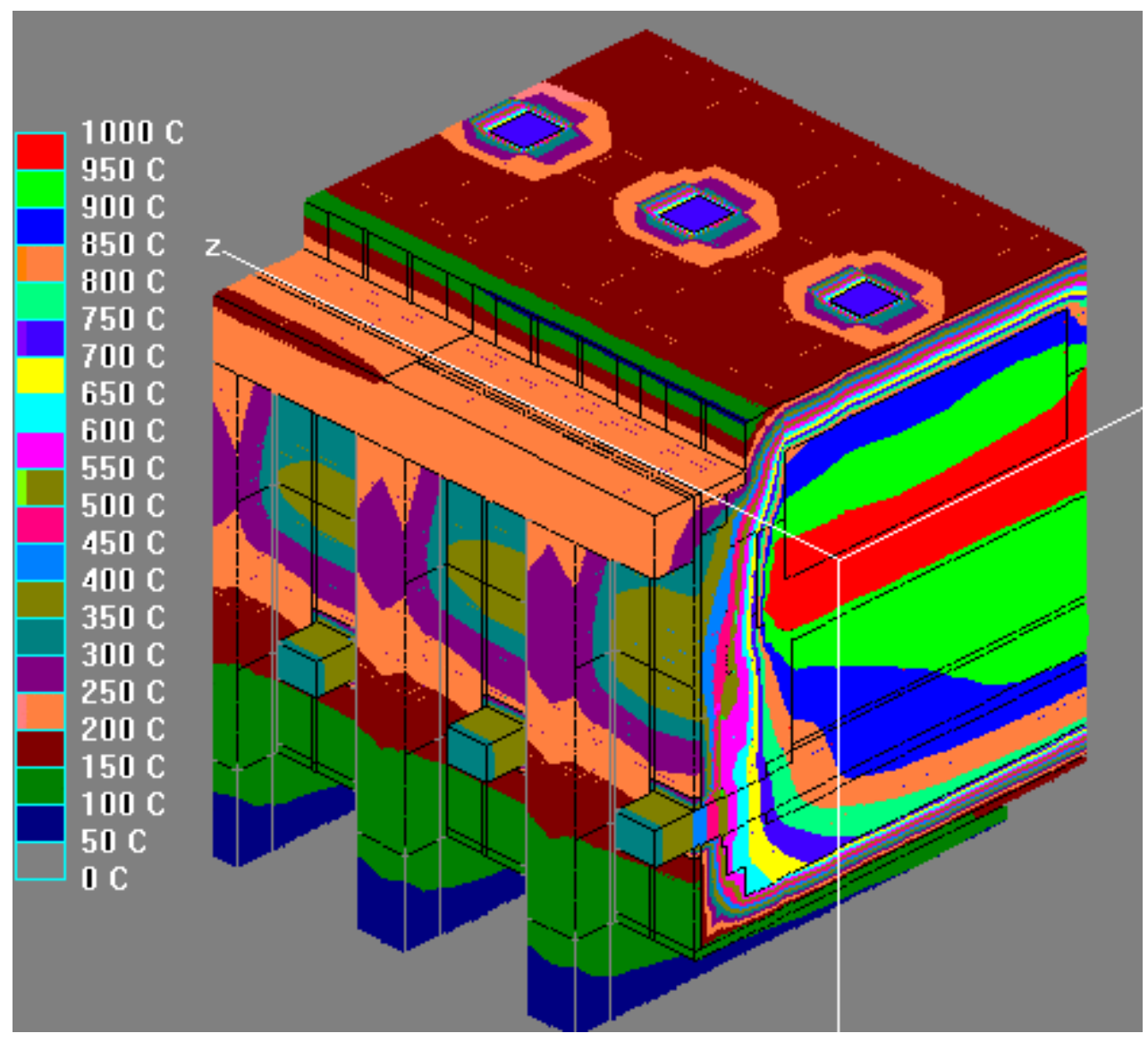

Figure 17 - Representative Thermal Model Output 
Table III - TiB2 Cell Parameter Estimate

\begin{tabular}{|c|c|c|}
\hline Plant & MEAD & MEAD \\
\hline Cell Type & $\mathrm{TiB}_{2}$ & Standard Cell \\
\hline & & \\
\hline & Superheat $=15$ & \\
\hline Amperages $(\mathrm{kA})$ & 71.0 & 71.0 \\
\hline Anode dimension L (cm) & 67.3 & 67.3 \\
\hline Width $(\mathrm{cm})$ & 39.4 & 39.4 \\
\hline Number of anodes & 22 & 24 \\
\hline $\begin{array}{l}\text { Number of dummy } \\
\text { anodes }\end{array}$ & 2 & 0 \\
\hline $\begin{array}{l}\text { Nominal Anode Current } \\
\text { Density }\left(\mathrm{Amps} / \mathrm{cm}^{2}\right)\end{array}$ & 1.218 & 1.116 \\
\hline Cell Gross Volts (volts) & 4.170 & 4.86 \\
\hline Controller Volts & 4.06 & 4.75 \\
\hline & & \\
\hline $\mathrm{kg}-\mathrm{Al} /$ PotDay & 537.5 & 537.5 \\
\hline $\begin{array}{l}\text { Anode cathode distance } \\
\text { (cm) }\end{array}$ & 2.4 & 4.2 \\
\hline Cell Power (kW) & 296.1 & 345.1 \\
\hline $\mathrm{DCKWH} / \mathrm{kg}-\mathrm{Al}$ & 13.22 & 15.44 \\
\hline Heat Balance ------------- & & \\
\hline Reaction Heat (kW) & 144.0 & 144.0 \\
\hline External Heat $(\mathrm{kW})$ & 22.8 & 22.8 \\
\hline Heat to Dissipate (kW) & 129.4 & 179.0 \\
\hline Cathode Heat Loss (kW) & 73.3 & 123.0 \\
\hline Top Heat Loss $(\mathrm{kW})$ & 56.1 & 56.1 \\
\hline Metal Depth (cm) & 0.1 & 9.9 \\
\hline
\end{tabular}




\section{“Scaledown" of Industrial Cell to Pilot Cell}

General:

1. Rectifier capacity at Reynolds test facility allowed $25 \mathrm{kA}$ operation.

2. Basic design was settled as $1 / 3$ of a standard Mead cell ( 8 of 24 anodes). Full sized Mead anodes were to be used, and the cathode shell was to be the same width as a standard Mead cell.

3. Sump size and shape were to be as designed for the full sized cell.

Amperage and anode current density

4. Cathode lining was scaled down to fit the length of the pilot cell shell. Insulation thicknesses were not changed. Cathode heat loss was calculated using Kaiser's thermal model.

5. Due to different surface to volume ratio of the two cells, the ACD at comparable anode current density was too high. Amperage target was adjusted upward by $19 \%$ to yield the same ACD as industrial cell. (See Table IV " Pilot Cell Performance Parameters").

\section{Results of Operation of Pilot Cell 1 as Applied to Lining Design}

1. Operation at $2.5 \mathrm{~cm}$ ACD was achieved.

2. The sump did not freeze or muck up as feared, and it did maintain ledge on the three outside walls.

3. Bottom and lower sidewall insulation remained intact.

4. The upper sidewall blocks were not eroded, indicating that they were protected by frozen bath ledge during operation.

5. Some areas of the upper side and endwall insulation were significantly penetrated by bath. This led to partial loss of insulating value.

6. The assumptions used for heat transfer coefficients were validated by the operational results.

\section{Design of Pilot Cell 2}

1. The insulation package was the same as for PC 1 except for an adjustment of the endwall insulation thickness and addition of a steel plate barrier in the side and endwalls.

2. The sump design of PC 1 was retained.

\section{Results of Operation of Pilot Cell 2 as Applied to Lining Design}

1. This cell was operated for long periods of energy input well above the design level, resulting in extensive sidewall erosion.

2. There was significant erosion of the inside wall of the sump. 


\section{Redesign of Industrial Cell}

1. Sump: The sump was redesigned to facilitate coverage of the sides with $\mathrm{TiB}_{2}-\mathrm{C}$ tiles.

2. Thermal design: Kaiser's thermal model was again used to simulate heat loss and ledge shape and the lining insulation package was finalized.

Table IV - Pilot Cell Performance Parameters

\begin{tabular}{|c|c|c|c|}
\hline \multirow{3}{*}{$\begin{array}{l}\text { Plant } \\
\text { Cell Type }\end{array}$} & MEAD & Pilot & Pilot \\
\hline & $\mathrm{TiB}_{2}$ & $\mathrm{TiB}_{2}$ & $\mathrm{TiB}_{2}$ \\
\hline & & $\begin{array}{c}\text { Same Current } \\
\text { density }\end{array}$ & $\begin{array}{l}\text { Increased current } \\
\text { density }\end{array}$ \\
\hline Superheat & 15 & 15 & 15 \\
\hline & & & \\
\hline Amperages $(\mathrm{kA})$ & 71.0 & 19.4 & 23.1 \\
\hline Anode dimension $\mathrm{L}(\mathrm{cm})$ & 67.3 & 67.3 & 67.3 \\
\hline Width(cm) & 39.4 & 39.4 & 39.4 \\
\hline Number of anodes & 22 & 6 & 6 \\
\hline $\begin{array}{l}\text { Number of dummy } \\
\text { anodes }\end{array}$ & 2 & 2 & 2 \\
\hline $\begin{array}{l}\text { Nominal Anode Current } \\
\text { Density }\left(\mathrm{Amps} / \mathrm{cm}^{2}\right)\end{array}$ & 1.218 & 1.22 & 1.45 \\
\hline Cell Gross Volts (volts) & 4.170 & 5.15 & 4.76 \\
\hline Current Efficiency, \% & 93 & 93 & 93 \\
\hline kg-Al/PotDay & 537.5 & 143.7 & 171.2 \\
\hline $\begin{array}{l}\text { Anode cathode distance } \\
\text { (cm) }\end{array}$ & 2.4 & 4.1 & 2.5 \\
\hline Cell Power (kW) & 296.1 & 99.9 & 110.0 \\
\hline $\mathrm{DCKWH} / \mathrm{kg}-\mathrm{Al}$ & 13.22 & 16.7 & 15.4 \\
\hline Heat Balance ----------- & & & \\
\hline Reaction Heat $(\mathrm{kW})$ & 144.0 & 38.8 & 46.2 \\
\hline External Heat (kW) & 22.8 & 6.3 & 8.9 \\
\hline Heat to Dissipate (kW) & 129.4 & 54.9 & 54.9 \\
\hline Cathode Heat Loss (kW) & 73.3 & 32.3 & 32.3 \\
\hline Top Heat Loss (kW) & 56.1 & 22.6 & 22.6 \\
\hline
\end{tabular}




\section{DISCUSSION}

This project showed great promise in developing the materials and technology for developing wettable cathode technology for an alumina reduction cell. Through testing in a $23 \mathrm{kA}$ pilot cell, the following items were accomplished:

- Confirmed best material composition at TiB2 with low carbon content, to survive long term in molten aluminum/bath environment

- Identified suitable method for tiles - interlocking hexagonal design

- Confirmed operation at 1" anode-tile distance

- Confirmed concept and viability of drained end-sump operation

- Demonstrate operation with enhanced cathode package

- Develop operational procedures for industrial cell

However, despite these accomplishments several key hurdles must be overcome in designing and operating an industrial cell in a drained cathode configuration. These items are:

- Proper thermal design for industrial cell

As illustrated in the pilot cell operation, if proper thermal balance is not achieved, providing proper ledge protection of the sidewalls, then long term operation of the cell cannot be maintained. This is no different than that of a conventional cell operation, but does introduce significant challenges in that thermal models are not fully calibrated for operation of a cell without a metal pad.

- Means for extinguishing anode effects

The pilot cell extinguished anode effects by turning the current off to the cell. This mode of extinguishing anode effects in an operating plant is impractical, and other methods must be developed and tested in a commercial cell.

- Means for protecting the sump

As seen the repetitive exposure to metal and bath results in dissolution of unprotected carbon surfaces. A means to protect the sump is critical to longterm operation; probably utilizing protective wettable ceramic tiles will be the most appropriate method.

These items had not been completely resolved at the ending of the project; however, it is believed that they can be resolved.

Recommendations for future work:

- The materials set from PC 2 appears suitable for full scale industrial cell testing. Extrapolated tile life expectancy exceeds current pot life. The tiles themselves do not appear to require unusual operational procedures above and beyond normal cell procedures. 
- Sump erosion protection will be required prior to further testing. A means of protecting the sump with the same tiles as used for the PC 2 cathode would be a suitable material for this application as well. Issues remain related to the cost of this design, as well as the impact on thermal performance of the sump, and available space for metal and its effect on tapping frequency.

Should industrial cell testing prove out the materials set and drained configuration operations, additional work will be required to scale-up the tile making process to meet industrial level requirements at suitable cost. Development of near-net shaping and capital expenditures for appropriate presses and furnaces would be required to meet the potential needs of the industry.

While operation of the pilot cell was directed toward material evaluation and proving the concept of the drained cathode configuration, some insight as to its benefits was seen both through its operation and modeling when compared to conventional metal pad operation. It was seen that operation at 1" anode-to-tiles distance could be achieved in the drained mode operation with no significant effects on current efficiency. In modeling the conventional Mead cell, this would result in a significant reduction in cell voltage of 0.7 volts or about a $15 \%$ reduction in energy usage. Due to the preliminary aspects of the material development no estimate is available as to increased cost of the ceramic tiles. These aspects would have to be evaluated as the testing is scaled up to commercial cell quantities. 
Appendix A

\section{Project Scope Description}




\section{STATEMENT OF OBJECTIVES}

\section{INTRODUCTION}

The materials used in the Hall-Heroult process to electrowin aluminum from alumina have not changed fundamentally since its development. A ceramic material, titanium diboride $\left(\mathrm{TiB}_{2}\right)$, has shown promise as the cathode surface in alumina reduction cells. $\mathrm{TiB}_{2}$ materials exhibit excellent resistance to aluminum metal and cryolite corrosion, good electrical conductivity, and maintain good strength at high temperatures. However, recent research has shown limited success for a number of reasons: difficulty in fabricating complex $\mathrm{TiB}_{2}$ shapes, inadequate cell designs, etc.

A new proprietary ceramic material " 312 " has shown potential for use as a reduction cell cathode. "312" has high electrical conductivity, thermal shock resistance, and is easily machinable. Its corrosion resistance in the reduction cell environment has not been fully evaluated.

\section{SCOPE}

The goal of this multi tasked research program is to develop the ceramic based materials, technology, and necessary engineering packages to retrofit existing reduction cells in order to reduce the energy consumption required for making primary aluminum. The ceramic materials will be used in a drained cathode configuration which will provide a stable, molten aluminum wetted cathode surface. By eliminating the wavy, irregular molten aluminum pool as the cathode surface and replacing it with the stable ceramic surface, the anode-to-cathode distance can be reduced, thereby reducing the electrical resistance.

Upon completion of the project, a nominal $70 \mathrm{kA}$ Hall-Heroult cell with a "drained cathode" will have been continuously operated for a period of six months. The cell operating targets are:

(1) Anode-cathode distance: $=1.0$ inch

(2) $93 \%$ current efficiency

(3) Cell voltage: 4.1 to 4.3 volt set point

(4) Energy consumption: Reduction of energy consumption by $10 \%$ to $6.25 \mathrm{kWh} / \mathrm{lb} \mathrm{Al}$

Stable operation of the TiB2-drained cathode technology will require the development of new process control algorithms for the management of alumina feeding, anode bridge movements, and increased sensitivity to cell instability indices.

Operation of a $70 \mathrm{kA}$ industrial prebake cell will provide the performance data and an assessment of the longevity of the $\mathrm{TiB}_{2}$-based materials needed to conduct an evaluation of the economic benefits of the $\mathrm{TiB}_{2}$-drained cathode technology before any expansion of the technology can be integrated into the aluminum industry. 
The program will be divided into three major tasks: 1) manufacture and laboratory scale testing/evaluation of ceramic materials, 2) pilot scale testing of qualified candidate compositions from the first task, and 3) retrofitting and testing materials in an industrial cell at the Kaiser Mead Plant at Spokane, Washington facility.

\section{TASK 1 - MATERIAL DEVELOPMENT}

The objective of this task is to develop, manufacture, and control the quality of production of wettable ceramic-based cathode lining materials for the Hall-Heroult cells.

\subsection{Subtask 1.1 - Develop Sample Materials for the Laboratory Tests}

Advanced Refractory Technologies, Inc. (ART) of Buffalo, New York will fabricate and evaluate small samples of $\mathrm{TiB}_{2}$ and " 312 " based materials for preliminary laboratory scale tests. ART will develop fabrication capabilities for composite preparations (including powder mixing, pressing and firing methods). The ceramic powders will be characterized by determining their impurity levels, particle size, grain morphology by SEM, surface area, and loss of weight at elevated temperatures by TGA. These characterizations will be used by ART to develop a quality control program for the production of wettable ceramic-based cathode lining materials for Hall-Heroult cells.

A minimum of two different compositions and two different methods of fabrication will be evaluated. Solid shapes and coatings will be made from different levels of TiB2 and "312" in the base compositions. At least ten 1" diameter by 1" thick discs will be made from each composition for testing. Samples of " 312 " will be prepared similarly using powders from existing synthesis methods and purities.

\subsection{Subtask 1.2 - Develop Quality Control Program}

The characterizations of sample cathode materials performed in task 1.1 will be used by ART to develop a quality control program for the production of wettable ceramicbased cathode lining materials for Hall-Heroult cells. This program will include specifications for the raw materials and cathode material fabrication methods. A raw material and manufactured component database will be established for the life of the project. Any ceramic cathode material failures will be analyzed to determine the mechanism(s) responsible for the failures, including how the raw materials, fabrication processes and operational conditions contributed to the failures.

\subsection{Subtask 1.3 - Laboratory Scale Tests of the Sample TiB2 and "312” Based Materials}

The tests will consist of immersing each sample in an electrolysis cell containing molten cryolite and aluminum for approximately 3 days. After testing, the samples will be visually inspected for corrosion and sectioned for SEM impurity analyses. 
From the results of the above screening tests, additional samples will be fabricated for extended electrolysis testing. Full size samples, approximately $12 \times 15.5$ x 0.5 inches, will be tested in an electrolysis cell for up to 2 weeks. New and/or "exposed" samples will be characterized by SEM, thermal gravimetric analysis (TGA), and if necessary, thermal shock measurements.

\section{TASK 2 - EVALUATION OF “312” AND TIB 2 MATERIALS IN 23 KA DRAINED PILOT REDUCTION CELL}

The objective of this task is to assess the durability of the " 312 " and $\mathrm{TiB}_{2}$-based materials in a molten aluminum/cryolite environment, and quantify the operation of the "drained" cathode design in $23 \mathrm{kA}$ pilot aluminum electrolysis cell tests.

Candidate materials will be selected for the pilot scale testing based on the results of the laboratory tests performed in Task 1 . The performance of the candidate " 312 " and/or $\mathrm{TiB}_{2-}$ based lining materials and the drained cathode design will be evaluated in two 1-to- 2 month $23 \mathrm{kA}$ pilot reduction cell tests.

The first pilot cell will be constructed of several of the candidate materials for evaluation, while the second cell will use only the most promising material. Both operations will be constructed in a "drained" cathode configuration that will allow operation of the cell at a reduced anode cathode distance.

The pilot cell will be constructed using conventional industrial cathode blocks modified with the ceramic-based materials in the special "drained" configuration. The cathode will utilize a special "tapping well" to contain the production of molten aluminum. Startup, design, and operation of the pilot cell will be similar to that of an industrial $\mathrm{TiB}_{2}$-based reduction cell. The pilot cell will be operated using the same industrial prebake anodes used at the Kaiser Mead smelter. The routine operations of the pilot cell will be in the same manner as the industrial cells; anode changing, metal tapping, alumina feeding, voltage control, etc. The pilot cell may be operated at a higher anode current density than the Kaiser cells to ensure thermal stability.

The condition of the wettable ceramic-based materials will be assessed from the results obtained from the cathodes autopsies conducted when the cell are stopped at the completion of the test period. The results of this assessment will be incorporated into the quality control program developed under Task 1 for the production of wettable ceramic-based cathode materials. Assessments of the lining and operation will also be done, providing direction for the industrial cell design. 


\section{TASK 3 - DEVELOPMENT OF ENGINEERING PACKAGES AND CONFIRMATION OF THE ECONOMICS FOR INDUSTRIAL CELLS OPERATING WITH TIB 2 -DRAINED CATHODES}

The objective of this task is to develop the engineering packages for industrial cells operating with $\mathrm{TiB}_{2}$ drained cathodes, characterize their performance (energy savings and metal production), and validate their economics.

One industrial $70 \mathrm{kA}$ prebake reduction cell will be designed and constructed with retrofit $\mathrm{TiB}_{2}$-drained cathodes. It will be operated for a period of 6 months at the Kaiser Mead aluminum smelter located in Spokane, Washington.

Startup and routine operation of the industrial prebake cell retrofitted with TiB2-drained cathodes will follow formal procedures developed by Kaiser and Alcoa. All required routine cell operations, including anode change, metal tapping, voltage control, alumina feeding, will be conducted by Kaiser personnel assigned to the project. Kaiser personnel will oversee the operations of the cell, with Alcoa personnel serving in a consulting mode.

Documentation of the performance of the $\mathrm{TiB}_{2}$-based retrofitted cell will be accomplished primarily by routine plant performance data:

1. Metal production as measured by individual cell tapping

2. Energy consumption by individual cell voltage and line current

3. Metal analysis by individual cells

4. Electrolyte chemistry of individual cells

5. Stability of individual cells

Special analysis or testing may be conducted if deemed needed during the test period by Kaiser or Alcoa. This could include such items as ledge profiling, cathode surface profiling, and thermal evaluations.

Following the six month test period the cell will be shutdown for cathode and lining autopsies.

\section{TASK 4 - PROJECT MANAGEMENT AND REPORTING}

The contractor, using its best efforts, is responsible to provide those management functions necessary to maintain the budget and schedule within established limits, seek early identification and resolution of technical and management problems, and maintain communications with all project participants, DOE and its technical representatives. In addition, the Contractor is responsible to provide the necessary personnel, materials, equipment, and facilities to perform and document the results of Tasks 1-3 within the authorized budget and schedule.

Reports will include monthly verbal technical status reports to the DOE project manager, quarterly written reports, annual topical reports, and a final report. The annual report will 
describe the technical progress of the project during the preceding twelve month budget period. Project review meetings will be held annually to review the progress of the project and make a go/no go determination as to the continuation of the project. 


\section{APPENDIX B}

\section{List of Publications}

1. Guy Fredrickson and Alton Tabereaux, "FY1 Technical Progress Report, October 1, 1997 to September 30, 1998, Wettable Ceramic-Based Drained Cathode

Technology for Aluminum Electrolysis", November 12, 1998,

2. Tom Alcorn, "Transmittal of FY2 Technical Progress Report Covering the Period of October 1, 1998 to September 30, 1999 for Wettable Ceramic-Based Drained Cathode Technology for Aluminum Electrolysis, DE-FC07-97ID13567”, December 11,2000

3. Tom Alcorn, "Transmittal of FY3 Technical Progress Report Covering the Period of October 1, 1999 to September 30, 2000 for Wettable Ceramic-Based Drained Cathode Technology for Aluminum Electrolysis, DE-FC07-97ID13567”, December 11,2000 
APPENDIX C

PATENT APPLICATION(S) GENERATED UNDER CONTRACT

\begin{tabular}{|c|c|c|c|c|c|c|c|c|c|c|}
\hline Job No. & $\begin{array}{l}\text { Government } \\
\text { Contract No. } \\
\text { (Case No.) }\end{array}$ & Inventor(s) & Title & $\begin{array}{l}\text { Serial No. } \\
\text { Filing Date }\end{array}$ & $\begin{array}{l}\text { Patent No. } \\
\text { Issue Date }\end{array}$ & $\begin{array}{l}\text { Report IR to } \\
\text { Govt. }\end{array}$ & $\begin{array}{l}\text { Report U.S. } \\
\text { Filing to Govt. }\end{array}$ & $\begin{array}{l}\text { Report Foreign } \\
\text { Filing to Govt. }\end{array}$ & Foreign Filing Date & $\begin{array}{l}\text { Send Copy of U.S. } \\
\text { Patent to Govt. }\end{array}$ \\
\hline $\begin{array}{l}\text { IP200100 } \\
2323 \\
\text { (GPT) }\end{array}$ & $\begin{array}{l}\text { DE-FC07- } \\
\text { 97ID13567 } \\
\text { (no S\# } \\
\text { assigned yet) }\end{array}$ & $\begin{array}{l}\text { Tabereaux, Jr., A.T. } \\
\text { Fredrickson, G.L. } \\
\text { Groat, E. } \\
\text { Mroz, T. } \\
\text { Ulicny, A. } \\
\text { Walker, M.F. }\end{array}$ & $\begin{array}{l}\text { Interlocking Wettable } \\
\text { Ceramic Tiles }\end{array}$ & $\begin{array}{l}10 / 206,472 \\
\text { July } 29,2002\end{array}$ & (none yet) & & 08-30-2002 & & & \\
\hline
\end{tabular}

